\title{
Neuroprotective and Cognitive Enhancement Potentials of Baicalin: A Review
}

\author{
Kandhasamy Sowndhararajan *, Ponnuvel Deepa, Minju Kim, Se Jin Park and Songmun Kim * (D) \\ School of Natural Resources and Environmental Science, Kangwon National University, \\ Chuncheon 24341, Gangwon-do, Korea; taanishadeepa@gmail.com (P.D.); camin1121@gmail.com (M.K.); \\ sejinpark@kangwon.ac.kr (S.J.P.) \\ * Correspondence: sowndhar1982@gmail.com (K.S.); perfume@kangwon.ac.kr (S.K.); Tel.: +82-33-250-6447
}

Received: 21 May 2018; Accepted: 8 June 2018; Published: 11 June 2018

\begin{abstract}
Neurodegenerative diseases are a heterogeneous group of disorders that are characterized by the gradual loss of neurons. The development of effective neuroprotective agents to prevent and control neurodegenerative diseases is specifically important. Recently, there has been an increasing interest in selecting flavonoid compounds as potential neuroprotective agents, owing to their high effectiveness with low side effects. Baicalin is one of the important flavonoid compounds, which is mainly isolated from the root of Scutellaria baicalensis Georgi (an important Chinese medicinal herb). In recent years, a number of studies have shown that baicalin has a potent neuroprotective effect in various in vitro and in vivo models of neuronal injury. In particular, baicalin effectively prevents neurodegenerative diseases through various pharmacological mechanisms, including antioxidative stress, anti-excitotoxicity, anti-apoptotic, anti-inflammatory, stimulating neurogenesis, promoting the expression of neuronal protective factors, etc. This review mainly focuses on the neuroprotective and cognitive enhancement effects of baicalin. The aim of the present review is to compile all information in relation to the neuroprotective and cognitive enhancement effects of baicalin and its molecular mechanisms of action in various in vitro and in vivo experimental models.
\end{abstract}

Keywords: baicalin; cognitive; neurodegenerative disease; neuroprotective; Scutellaria baicalensis

\section{Introduction}

Scutellaria baicalensis Georgi (Lamiaceae or Labiatae) is an important Chinese traditional medicinal plant, and commonly known as Huang-Qin or Chinese skullcap (Radix scutellariae). Traditionally, the root part of this plant has been used for the treatment of various ailments, including diarrhea, hepatitis, atherosclerosis, dysentery, diabetes, hypertension, complication of menstruation, eye diseases, vomiting, hemorrhaging, insomnia, common cold, inflammation, and respiratory infections [1]. Further, several scientific studies have reported that extracts and isolated compounds from S. baicalensis have various pharmacological properties, such as antitumor, hepatoprotective, antimicrobial, anti-inflammatory, neuroprotective, anti-hyperlipidemic, antidiabetic, antimutagenesis, anticonvulsant, and antioxidant. So far, more than 50 flavonoid components have been isolated and identified from $S$. baicalensis. Among them, baicalin and its aglycone baicalein are the major bioactive compounds [2,3].

Baicalin $\left(\mathrm{C}_{21} \mathrm{H}_{18} \mathrm{O}_{11} ; 5,6,7\right.$-trihydroxyflavone 7-O-beta-D-glucuronide or baicalein 7-O- $\beta$-Dglucuronic acid or 7-D-glucuronic acid-5,6-dihydroxyflavone) (Figure 1) is one of the most important flavonoid components in the roots of Scutellaria baicalensis Georgi. The concentration of baicalin in the roots of S. baicalensis ranged from $8.1 \%$ to $15.6 \%$ [4-7]. The root of this plant has been traditionally used for the treatment of numerous diseases in East Asia. Synonyms of S. baicalensis are S. grandiflora Adams, S. lanceolaria Miq., and S. macrantha. Baicalin is also the major constituent in other Scutellaria species, 
namely S. lateriflora, S. galericulata, and S. rivularia, as well as in Oroxylum indicum (Bignoniaceae). Different species of Scutellaria are mainly distributed in Asian countries, such as China, Russia, Mongolia, Japan, and Korea [8].

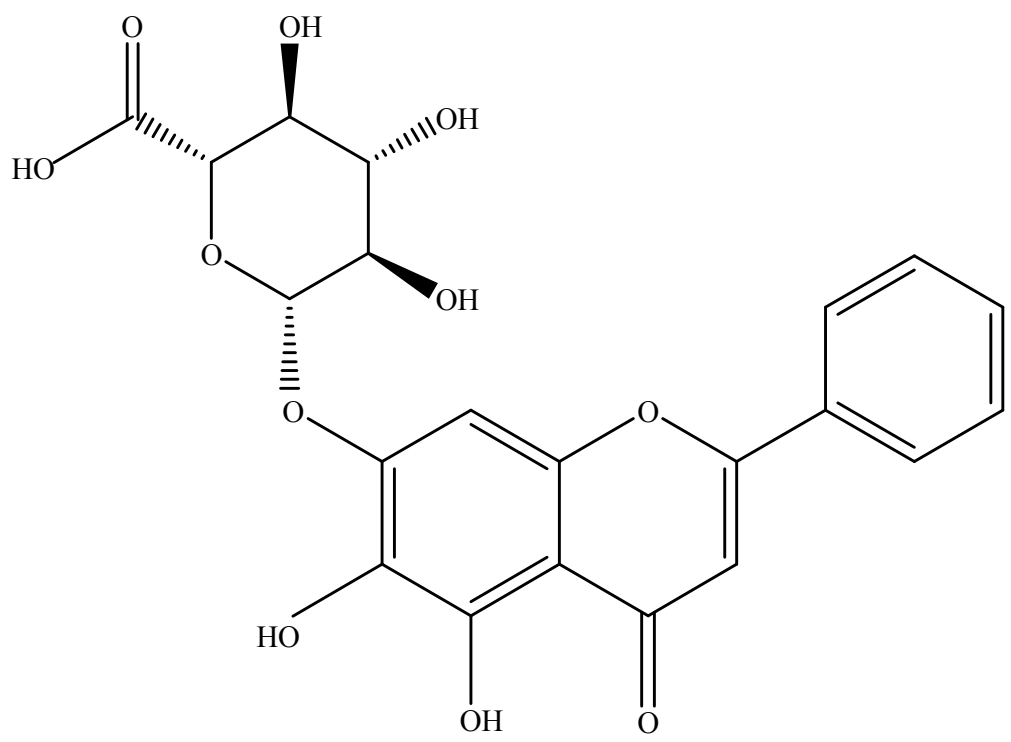

Figure 1. The chemical structure of baicalin.

Baicalin has been extensively used in pharmaceutical and food industries due to its outstanding bioactivities. A number of in vitro and in vivo studies have demonstrated that baicalin possesses various pharmacological properties, including anti-inflammatory, anticancer, antidiabetic, antithrombotic, cardioprotective, hepatoprotective, and neuroprotective properties [8,9]. In particular, baicalin exhibits a variety of beneficial effects in the central nervous system (CNS) by promoting neural differentiation and inhibiting neuronal apoptosis [10]. Further, baicalin also shows antidepressantand anxiolytic-like properties and improving cognitive performances [6]. Previous studies have demonstrated that baicalin showed protective effect against amyloid- $\beta$ (A $\beta)$, hydrogen peroxide $\left(\mathrm{H}_{2} \mathrm{O}_{2}\right)$, oxygen/glucose deprivation (OGD), middle cerebral artery occlusion (MCAO), ketamine, and thrombin-induced neurotoxicity in cell lines and animal models [11-16].

The brain and nervous system-related diseases affect over two billion people worldwide and many of the most harmful brain diseases are neurodegenerative. Chronic neurodegenerative diseases, including Alzheimer's (AD), Parkinson's (PD), and Huntington's diseases represent a large unmet medical need in the world. These diseases refer to those conditions in which neuronal cells undergo progressive degeneration and eventual death associated with aging [17]. Accumulating evidence suggests that excitotoxicity, oxidative stress, mitochondrial dysfunction, inflammatory response, protein misfolding, and neuronal apoptosis have been associated with neurodegeneration $[9,18]$. The most common symptoms of neurodegenerative diseases are anxiety, apathy, depression, motor dysfunction, and memory impairment [19]. Numerous studies have shown that baicalin efficiently prevents various neurodegenerative diseases, such as AD, PD, and cerebral ischemia, by suppressing oxidative stress, inhibiting excitotoxicity, and promoting neurogenesis, reducing apoptosis, and inhibiting the production of inflammatory cytokines $[9,20,21]$.

Previously, some authors clearly reviewed therapeutic potentials of baicalin against cancer, cerebral ischemia, tumor, cardiovascular, ocular, and inflammatory disorders [5,8,9,22-25]. However, the low aqueous solubility and poor oral bioavailability of baicalin are the major limitations in the clinical application. Baicalin showed limited permeability, probably owing to its comparatively high hydrophilicity and larger molecular weight. In addition, baicalin was found to be moderately absorbed in the stomach and poorly in the small intestine and colon [26]. Moreover, previous studies 
clearly demonstrated that baicalin can be detected in the blood of animals immediately after oral or intravenous administration of baicalein $[27,28]$. In regard to drug-drug interaction, baicalin may influence the metabolism of several CYP2E1 isozyme dependent drugs [29]. Previous study reported that following treatment with aminoglycoside, the absolute bioavailability of baicalin was decreased by nearly $40-45 \%$ when compared with untreated rats. Some studies exhibited that baicalin could interact with transporter-related drugs (rosuvastatin, and 7-ethyl-10-hydroxycamptothecin) and other drugs such as cyclosporine A, quinidine, and SKF-525A [9].

There has been no specific review of published articles in relation to neuroprotective and cognitive enhancement effects of baicalin. Herein, we reviewed the protective effects of baicalin on various neurodegenerative disorders. Current knowledge about neuroprotective and cognitive enhancement properties of baicalin and its molecular mechanisms are presented in Tables 1 and 2. Figure 2 illustrates the role of different signaling pathways in protecting neuronal damage.

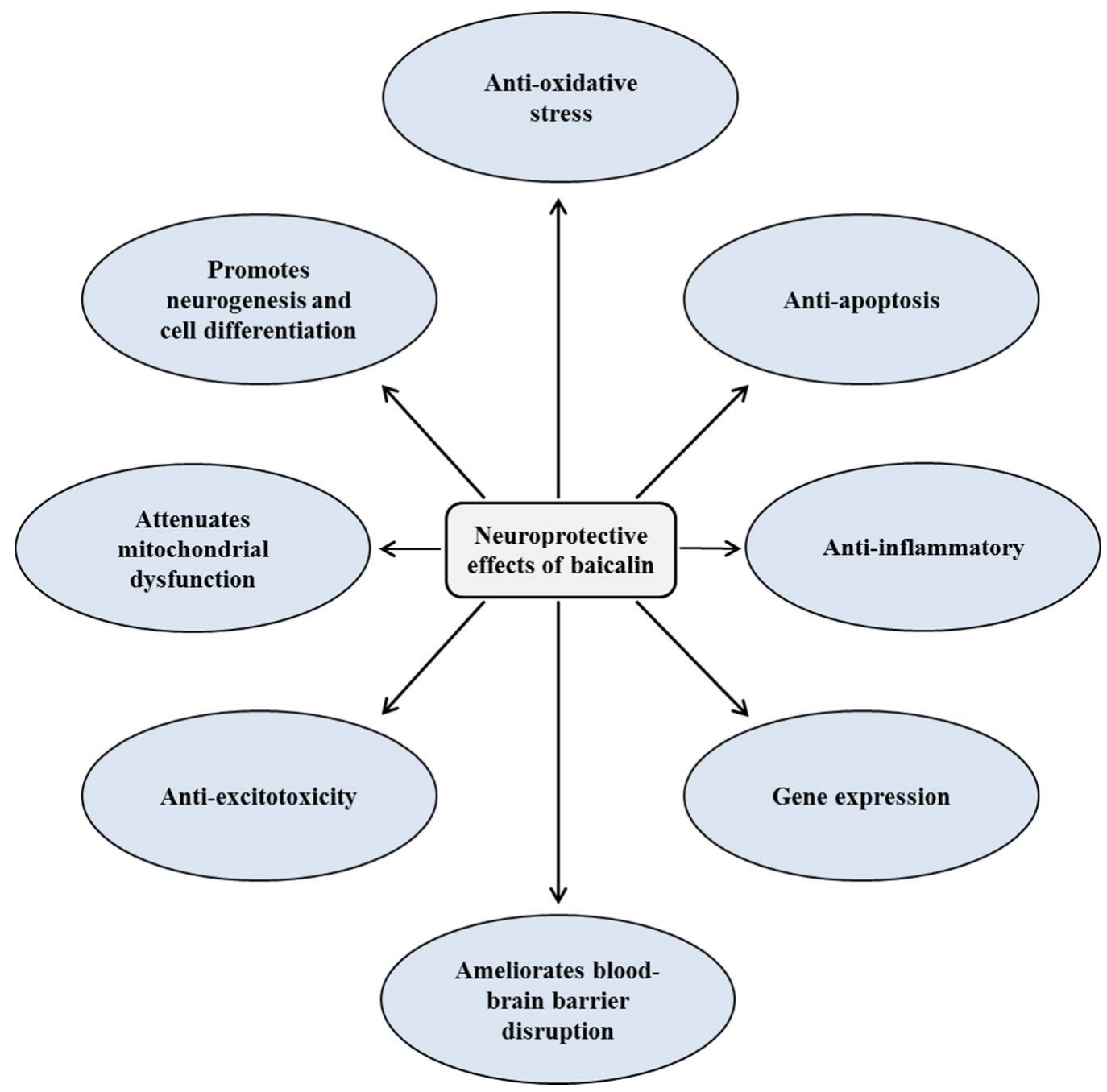

Figure 2. Mechanisms of neuroprotective and cognitive enhancement effects of baicalin. 
Table 1. Neuroprotective effects of baicalin under in vitro and ex vivo models.

\begin{tabular}{|c|c|c|c|c|}
\hline S. No. & Model & Mechanism & Dose & Reference \\
\hline 1 & $\begin{array}{l}\text { Oxygen/glucose deprivation (OGD)- and } N \text {-methyl-D-aspartate } \\
\text { (NMDA)-induced injuries in rat hippocampal slices }\end{array}$ & $\begin{array}{l}\text { Inhibited viability reduction and acute neuron swelling. Inhibited the increased membrane } \\
\text { portion of } \operatorname{PKC}(\alpha) \text {. }\end{array}$ & $\begin{array}{l}0.1,1 \text {, and } \\
10 \mu \mathrm{M} / \mathrm{L}\end{array}$ & [30] \\
\hline 2 & OGD-induced ischemic-like injury in rat cortical neurons & $\begin{array}{l}\text { Attenuated Injuries. Inhibited 5-LOX translocation to the nuclear envelope translocation. } \\
\text { Inhibited the production of cysteinyl leukotrienes. Decreased intracellular calcium level. }\end{array}$ & $0.2,1$, and $5 \mu \mathrm{M}$ & [31] \\
\hline 3 & Light-, $\mathrm{H}_{2} \mathrm{O}_{2}-$, and serum deprivation-induced toxicity in RGC- 5 cells & Attenuated the negative insult of light, $\mathrm{H}_{2} \mathrm{O}_{2}$, and serum withdrawal to RGC-5 cells. & $\begin{array}{l}0.1,0.5,1,5, \text { and } \\
10 \mu \mathrm{M}\end{array}$ & [32] \\
\hline 4 & Prolyl oligopeptidase (POP) inhibition assay & Inhibited POP in a dose-dependent manner. & $\begin{array}{l}20,50,100, \text { and } \\
150 \mu \mathrm{M}\end{array}$ & [33] \\
\hline 5 & OGD-induced toxicity in $\mathrm{BC} 2, \mathrm{PC} 12$ and primary neuron cells & Downregulated the expression of NOD2 and TNF $\alpha$. & $10 \mu \mathrm{g} / \mathrm{mL}$ & [34] \\
\hline 6 & A $\beta$-induced toxicity in SH-SY5Y cells & Inhibited $A \beta_{1-42}$ aggregation. Protected oxidative injuries by decreasing $\mathrm{H}_{2} \mathrm{O}_{2}$ production. & $2.5,5$, and $10 \mu \mathrm{M}$ & [35] \\
\hline 7 & OGD-induced toxicity in rat microglial cells & $\begin{array}{l}\text { Suppressed the release of TNF- } \alpha, \text { IL-1 } \beta, \text { IL-6, and IL- } 8 \text {. Downregulated TLR4 mRNA } \\
\text { expression. Reduced TRAF6 levels. Downregulated the phosphorylation of IKB- } \alpha \text {, c-jun, } \\
\text { ERK1/2, JNK, p } 38 \text { and inhibited the transfer of MyD88 from cytoplasm to membrane. }\end{array}$ & $\begin{array}{l}10,20, \text { and } \\
40 \mu \mathrm{g} / \mathrm{mL}\end{array}$ & [36] \\
\hline 8 & $\begin{array}{l}\text { Neural stem/progenitor cells (NSPCs) from the cortex of embryonic } \\
\text { E15-16 rats }\end{array}$ & $\begin{array}{l}\text { Increased the percentages of MAP-2 positive-staining cells and decreased GFAP staining } \\
\text { cells. Downregulated the expression of p-stat } 3 \text { and Hes1. Upregulated the expressions of } \\
\text { NeuroD1 and Mash1. }\end{array}$ & 2 and $20 \mu \mathrm{M}$ & [37] \\
\hline 9 & $\mathrm{H}_{2} \mathrm{O}_{2}$-induced toxicity in primary rat cortical neurons & Attenuated neuronal injury and improved superoxide dismutase (SOD) activity. & $\begin{array}{l}10,20,40,80 \text {, and } \\
200 \mu \mathrm{M}\end{array}$ & [38] \\
\hline 10 & Colistin sulfate-induced toxicity in PC12 cells & $\begin{array}{l}\text { Changed the cell morphology and increased the cell viability. Decreased caspase-3 activity, } \\
\text { tate dehydrogenase level, and free radical content. }\end{array}$ & $\begin{array}{l}25,50, \text { and } \\
100 \mu \mathrm{g} / \mathrm{mL}\end{array}$ & [39] \\
\hline 11 & Peroxynitrite-mediated toxicity in SH-SY5Y cells & Protected the neuronal cell damage. & 5,20 , and $50 \mu \mathrm{M}$ & [40] \\
\hline 12 & OGD-induced injury in brain microvascular endothelial cells & 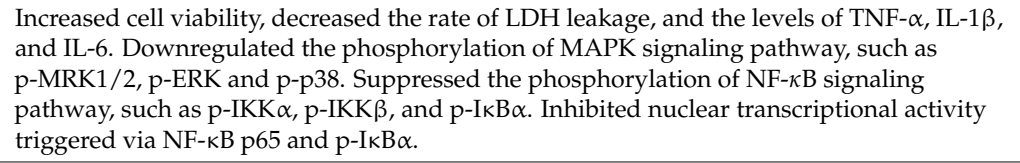 & 10 and $100 \mu \mathrm{M}$ & [41] \\
\hline 13 & NSPCs from rats & Transient exposure of NSPCs to baicalin during proliferation activated Mash1. & $7.5,15$, and $30 \mu \mathrm{M}$ & [42] \\
\hline
\end{tabular}


Table 1. Cont.

\begin{tabular}{|c|c|c|c|c|}
\hline S. No. & Model & Mechanism & Dose & Reference \\
\hline 14 & C6 glioma cells & $\begin{array}{l}\text { Downregulated iron concentration by positively regulating divalent metal transporter } 1 \\
\text { expression and negatively regulating ferroportin } 1 \text { expression. Decreased iron } \\
\text { accumulation in the substantia nigra. }\end{array}$ & $100 \mu \mathrm{g} / \mathrm{mL}$ & [43] \\
\hline 15 & $A \beta_{42}$-induced toxicity in BV2 microglial cells & $\begin{array}{l}\text { Reduced the expression of CD11b, decreased chemotactic ability, and inhibited the secretion } \\
\text { of IL-6, TNF- } \alpha \text {, and NO. Suppressed the phosphorylation of JAK2 and STAT3. }\end{array}$ & 50 and $100 \mu \mathrm{M}$ & [14] \\
\hline 16 & $\mathrm{H}_{2} \mathrm{O}_{2}$-induced toxicity in $\mathrm{PC} 12$ cells & $\begin{array}{l}\text { Reduced the viability loss and apoptotic rate. Increased SOD, GSH-Px activities, and } \\
\text { decreased MDA level. Increased the expression of survivin, Bcl-2, and p-STAT3, and } \\
\text { decreased caspase-3 expression. }\end{array}$ & 1,2 , and $5 \mu \mathrm{M}$ & [15] \\
\hline 17 & Thrombin-induced toxicity in SH-SY5Y cells & $\begin{array}{l}\text { Reduced cell death by inhibiting NF- } \mathrm{kB} \text { activation and suppressing PAR-1 expression. } \\
\text { Reduced caspase- } 3 \text { expression. }\end{array}$ & 5,10 , and $20 \mu \mathrm{M}$ & [12] \\
\hline 18 & Neuronal differentiation of human iPS cells & $\begin{array}{l}\text { Promoted neuronal differentiation and inhibited glial differentiation. Reduced Hes1 protein } \\
\text { levels and upregulated Ascl1 gene expression. }\end{array}$ & $10 \mathrm{mmol} / \mathrm{L}$ & [44] \\
\hline 19 & $\mathrm{H}_{2} \mathrm{O}_{2}$-induced toxicity in primary rat cortical neurons & $\begin{array}{l}\text { Inhibited neuronal apoptosis by enhancing the transcription and expression of MCL-1 and } \\
\text { BCL-2. Increased MRTF-A level. The anti-apoptosis effect of baicalin was inhibited by small } \\
\text { interfering RNA of MRTF-A. Enhanced the transactivity of MCL-1 and BCL-2 promoter. } \\
\text { LY294002 (PI3K inhibitor) and PD98059 (ERK1/2 inhibitor) reduced baicalin-induced } \\
\text { MRTF-A expression and transactivity and expression of MCL-1 and BCL-2. }\end{array}$ & $0.7,1.4$, and $2.8 \mu \mathrm{M}$ & [21] \\
\hline 20 & OGD/reoxygenation (RO)-induced toxicity in SH-SY5Y cells & $\begin{array}{l}\text { Attenuated apoptotic cell death. Decreased caspase-3 expression. Downregulated of NF-кB } \\
\text { and NMDAR1. }\end{array}$ & $\begin{array}{c}1,5, \text { and } \\
25 \mu \mathrm{mol} / \mathrm{L}\end{array}$ & [45] \\
\hline 21 & OGD-induced toxicity in hippocampal neurons and SH-SY5Y cells & Suppressed the phosphorylation level of CaMKII. & $1 \mu \mathrm{M}$ & [46] \\
\hline 23 & Cobalt chloride-induced toxicity in PC12 cells & Baicalin-berberine complex showed protective effects & $15 \mu \mathrm{g} / \mathrm{mL}$ & [47] \\
\hline 24 & $\mathrm{OGD} /$ reperfusion-induced toxicity in PC12 cells & $\begin{array}{l}\text { Inhibited Drp-1 expression, decreased mitochondrial fission, promoted MFN2 generation, } \\
\text { increased Drp-1 Ser637 phosphorylation, and elevated mitochondrial membrane potential. } \\
\text { Suppressed cell apoptosis and enhanced mitophagy. }\end{array}$ & $\begin{array}{l}0.1,1,10 \text {, and } \\
20 \mu \mathrm{M}\end{array}$ & [13] \\
\hline 25 & $\begin{array}{l}\text { OGD-induced toxicity in microvascular endothelial cells from } \\
\text { mouse brain }\end{array}$ & $\begin{array}{l}\text { Inhibited cell death, reduced cell membrane damage, and maintained the integrity of the } \\
\text { nucleus. Decreased the necroptosis ratio. Regulated the expression of RIP- } 1 \text { and RIP-3 in } \\
\text { bEnd. } 3 \text { cells. Inhibited the production of ROS and malondialdehyde. Increased the activity } \\
\text { of SOD. }\end{array}$ & 100 and $200 \mu \mathrm{M}$ & [48] \\
\hline 26 & Schwann cells (SCs) of RSC96 & Promoted the viability of RSC96 SCs and gene expression of GDNF, BDNF, and CNTF. & 5,10 , and $20 \mu \mathrm{M}$ & [49] \\
\hline 27 & $\begin{array}{l}\text { Dopamine-induced minimal hepatic encephalopathy in primary } \\
\text { hippocampal neurons }\end{array}$ & $\begin{array}{l}\text { Blocked dopamine-induced reduction of } \mathrm{GABA}_{\mathrm{A}} \mathrm{R} \text { levels. Improved the interaction of } \\
\mathrm{GABA}_{\mathrm{A}} \mathrm{R} \text { with TrkB. Prevents dopamine-induced impairment of synaptogenesis. }\end{array}$ & $\begin{array}{l}1,2.5,5,10 \text {, and } \\
\quad 30 \mu \mathrm{M}\end{array}$ & [50] \\
\hline
\end{tabular}


Table 2. Neuroprotective effects of baicalin under in vivo models.

\begin{tabular}{|c|c|c|c|c|}
\hline S. No. & Model & Mechanism & Dose & References \\
\hline 1 & $\begin{array}{l}\text { Middle cerebral artery occlusion } \\
\text { (MCAO)-induced focal cerebral ischemia in rats }\end{array}$ & Attenuated the elevations of Glu and Asp. & $300 \mathrm{mg} / \mathrm{kg}$, intra-sublingually & [51] \\
\hline 2 & Anxiolytic-like effects in mice & $\begin{array}{l}\text { Increased the number of shocks as measured in Vogel lick-shock conflict paradigm. Anxiolytic-like } \\
\text { effect baicalin was antagonized by a benzodiazepine receptor antagonist, flumazenil ( } 2 \mathrm{mg} / \mathrm{kg} \text {, ip). }\end{array}$ & $20 \mathrm{mg} / \mathrm{kg}$, ip & [52] \\
\hline 3 & MCAO-induced cerebral ischemia in rats & Reduced the infarction areas. Increased the gene expression of RpL19 and Csnk2. & $40 \mathrm{mg} / \mathrm{kg}$, po & [53] \\
\hline 4 & Anxiolytic-like effect in mice & $\begin{array}{l}\text { Increased entries into and time spent in open arms. Improved the performance in the hole-board and } \\
\text { horizontal wire tests. }\end{array}$ & $3.75,7.5,15$, and $30 \mathrm{mg} / \mathrm{kg}$, po & [54] \\
\hline 5 & $\begin{array}{l}\text { Focal cerebral ischemia-reperfusion injury } \\
\text { in rats }\end{array}$ & $\begin{array}{l}\text { Ameliorated the results of TTC and histological examination. Baicalin/jasminoidin combination } \\
\text { ameliorated DWI of MRI and behavior examination results. Promoted the expression of BDNF and } \\
\text { inhibited the expression of caspase-3. }\end{array}$ & $\begin{array}{l}\text { Baicalin-15 mg/ } / \mathrm{kg} \text {, or a combination of } \\
\text { baicalin }(15 \mathrm{mg} / \mathrm{kg}) \text { and jasminoidin } \\
\qquad(15 \mathrm{mg} / \mathrm{kg}), \text { iv }\end{array}$ & [55] \\
\hline 6 & $\begin{array}{l}\text { Heat stress on cerebrovascular and metabolic } \\
\text { functions in rats }\end{array}$ & $\begin{array}{l}\text { Improved survival during heatstroke. Reduced the hyperthermia, intracranial hypertension, and } \\
\text { increased levels of NO metabolite, glutamate, glycerol, lactate/pyruvate ratio, and dihydroxybenzoic } \\
\text { acid in the hypothalamus. Suppressed the levels of IL-1 } \beta \text { and TNF- } \alpha \text { in the serum and hypothalamus. }\end{array}$ & 10,20 , and $40 \mathrm{mg} / \mathrm{kg}$, iv & [56] \\
\hline 7 & MPTP-induced toxicity in mice & $\begin{array}{l}\text { Decreased score in the hanging and swimming tests. Prevented the loss of TH-positive neurons and } \\
\text { the decrease of dopamine content. Increased the content of GSH in the brain. }\end{array}$ & $100 \mathrm{mg} / \mathrm{kg}$, po & [57] \\
\hline 8 & Picrotoxin-induced seizure in mice & $\begin{array}{l}\text { Improved behavioral performances as measured in step-through passive avoidance and rotarod tests. } \\
\text { Showed preference for alpha2- and alpha3-containing } \mathrm{GABA}(\mathrm{A}) \text { subtypes. }\end{array}$ & $3.3,10$, and $30 \mathrm{mg} / \mathrm{kg}$, po & [58] \\
\hline 9 & Ischemic insult to retina of one eye of a rat & Regulated the localization of Thy- 1 and ChAT, and the content of various proteins and mRNAs. & $12.5 \mathrm{mg} / \mathrm{kg}$, ip & [32] \\
\hline 10 & MCAO-induced focal cerebral ischemia in rats & $\begin{array}{l}\text { Reduced neurological deficit scores and cerebral infarct volume. Decreased the enzymatic activity of } \\
\text { MPO and the expression of iNOS and COX-2. Inhibited neuronal apoptosis and the expression of } \\
\text { cleaved caspase-3 protein. }\end{array}$ & 10,30 , and $100 \mathrm{mg} / \mathrm{kg}$, ip & [59] \\
\hline 11 & MCAO-induced focal cerebral ischemia in mice & Performed well in regulating proteins in energy metabolism. & $20 \mathrm{mg} / \mathrm{kg}$, i.v & [60] \\
\hline 12 & Spinal cord injury (SCI) in rat & $\begin{array}{l}\text { Decreased the water content of spinal cord tissue, the permeability of blood-spinal cord barrier, } \\
\text { oxidant stress. Downregulated the expression of TNF- } \alpha \text {, NF-kB, Bax, Bcl-2, and caspase- } 3 \text {. Improved } \\
\text { the recovery of limb function. }\end{array}$ & 10,30 , and $100 \mathrm{mg} / \mathrm{kg}$, ip & [20] \\
\hline 13 & $\begin{array}{l}\text { Bilateral common carotid artery ligation } \\
\text { (BCCL)-induced cerebral ischemia in rats }\end{array}$ & Downregulated the expression of NOD2 and TNF $\alpha$ in protein levels. & 10 , and $50 \mathrm{mg} / \mathrm{kg}$, ip & [34] \\
\hline 14 & MCAO-induced focal cerebral ischemia in rats & $\begin{array}{l}\text { Decreased neurological deficit scores and reduced the volume of infarction. Decreased the level of } \\
\text { NF- } k \text { B p } 65 \text {. }\end{array}$ & 50,100 , and $200 \mathrm{mg} / \mathrm{kg}$, ip & [61] \\
\hline 15 & $\begin{array}{l}\text { Occlusion of common carotid arteries-induced } \\
\text { ischemia in gerbils }\end{array}$ & $\begin{array}{l}\text { Attenuated neuronal cell damage. Reduced the level of MDA. Elevated SOD, GSH, and GSH-PX } \\
\text { activities. Promoted the expression of BDNF and inhibited the expression of caspase-3. }\end{array}$ & 50,100 , and $200 \mathrm{mg} / \mathrm{kg}$, ip & [62] \\
\hline 16 & MCAO-induced focal cerebral ischemia in rats & $\begin{array}{l}\text { Reduced the neuronal damage, brain edema, and blood-brain barrier (BBB) permeability. } \\
\text { Downregulated the expression of MMP-9 protein and mRNA. Upregulated the expression of occludin. }\end{array}$ & $100 \mathrm{mg} / \mathrm{kg}$, ip & [63] \\
\hline
\end{tabular}


Table 2. Cont

\begin{tabular}{|c|c|c|c|c|}
\hline S. No. & Model & Mechanism & Dose & References \\
\hline 17 & MCAO-induced cerebral ischemia in rats & $\begin{array}{l}\text { Reduced cerebral infarct area and infarct volume. Decreased the expression of TLR2 } / 4, \mathrm{NF}-\mathrm{kB} \text {, iNOS, } \\
\text { and COX-2. Attenuated TNF- } \alpha \text { and IL- } 1 \beta \text { levels. }\end{array}$ & $100 \mathrm{mg} / \mathrm{kg}$, ip & [64] \\
\hline 18 & Global ischemia/reperfusion injury in rats & $\begin{array}{l}\text { Improved learning and memory. Decreased hippocampal apoptosis and reduced the level of } \\
\text { COX-2 expression. }\end{array}$ & $100 \mathrm{mg} / \mathrm{kg}$, po & [65] \\
\hline 19 & $\begin{array}{l}\text { 4-vessel occlusion-induced global ischemic } \\
\text { model in rat }\end{array}$ & Inhibited the hippocampal neuronal cell death. & $10 \mathrm{mg} / \mathrm{kg}$, po & [66] \\
\hline 20 & Pilocarpine-induced epileptic model in rats & $\begin{array}{l}\text { Delayed the onset of the first limbic seizures and status epilepticus. Reduced the mortality rate, and } \\
\text { attenuated the changes of lipid peroxidation, nitrite content, and reduced glutathione levels. } \\
\text { Attenuated the neuronal cell loss, apoptosis, and degeneration. }\end{array}$ & $100 \mathrm{mg} / \mathrm{kg}$, ip & [67] \\
\hline 21 & $\begin{array}{l}\text { BCCL-induced cerebral ischemia-reperfusion } \\
\text { in rats }\end{array}$ & Prolonged the terminal half-life of baicalin & $90 \mathrm{mg} / \mathrm{kg}$, iv & {$[68]$} \\
\hline 22 & Rotenone-induced Parkinson's disease in rats & Inhibited iron accumulation in different brain regions. & $78 \mathrm{mg} / \mathrm{kg}$, po & [69] \\
\hline 23 & Collagenase VII-induced ICH in rats & Attenuated brain edema and inhibited cell apoptosis. Suppressed the expression of PAR-1. & 25,50 , or $100 \mathrm{mg} / \mathrm{kg}$, ip & [70] \\
\hline 24 & MCAO-induced cerebral ischemia in rats & $\begin{array}{l}\text { Improved neurological function and decreased brain infarction. Reduced cell apoptosis and inhibited } \\
\text { the production of ROS and MDA. Interfered with SOD and NOX oxidase activities. }\end{array}$ & $15 \mathrm{mg} / \mathrm{kg}$, iv & [38] \\
\hline 25 & $\begin{array}{l}\text { Bilateral common carotid arteries } \\
\text { (BCCA)-induced global ischemia/reperfusion } \\
\text { injury in gerbils }\end{array}$ & $\begin{array}{l}\text { Facilitated neurological function and suppressed neuronal damage. Increased GABA(A)R } \alpha 1 \text {, } \\
\text { GABA(A)R } \gamma 2 \text { and KCC2. Decreased NKCC1 level. Upregulated the protein expressions of HSP70 and } \\
\text { p-ERK, and diminished the expression of p-JNK and p-p38. }\end{array}$ & $200 \mathrm{mg} / \mathrm{kg}$, ip & [71] \\
\hline 26 & MCAO-induced cerebral ischemia in mice & $\begin{array}{l}\text { Out of the } 10 \text { most significant molecular functions, } 7 \text { were common to baicalin and controls, and only } 3 \\
\text { occurred in baicalin group. }\end{array}$ & $5 \mathrm{mg} / \mathrm{kg}$, iv & [72] \\
\hline 27 & $\begin{array}{l}\text { Chronic unpredictable mild stress } \\
\text { (CMS)-induced depressive-like behavior in rats }\end{array}$ & $\begin{array}{l}\text { Prevented the abnormalities induced by CMS. Decreased COX-2 activity and expression, and reduced } \\
\text { the level of PGE2. }\end{array}$ & 10,20 , and $40 \mathrm{mg} / \mathrm{kg}$, po & [73] \\
\hline 28 & MCAO-induced cerebral ischemia injury in rats & Inhibited the formation of 3-nitrotyrosine, reduced infarct size, and attenuated apoptotic cell death. & 10,25 , and $50 \mathrm{mg} / \mathrm{kg}$, iv & [40] \\
\hline 29 & Ibotenic acid-induced dementia in rats & $\begin{array}{l}\text { A combination of three chemicals attenuated abnormalities in cognition, brain functional images, and } \\
\text { brain histological morphology. Influenced the expression levels of } 19 \text { genes in the forebrain. }\end{array}$ & $\begin{array}{l}3 \mathrm{~mL} / \mathrm{kg}, \text { po }(1.25 \mathrm{mg} / \mathrm{mL} \text { baicalin, } \\
6.25 \mathrm{mg} / \mathrm{mL} \text { jasminoidin, and } \\
1.75 \mathrm{mg} / \mathrm{mL} \text { cholic acid })\end{array}$ & [74] \\
\hline 30 & $\begin{array}{l}\text { BCCA-induced transient cerebral ischemia } \\
\text { in rats }\end{array}$ & $\begin{array}{l}\text { Increased the number of newly generated cells and promoted new neuron production. Improved } \\
\text { cognitive impairment in Morris water maze test. }\end{array}$ & $50 \mathrm{mg} / \mathrm{kg}$, ip & [42] \\
\hline
\end{tabular}


Table 2. Cont

\begin{tabular}{|c|c|c|c|c|}
\hline S. No. & Model & Mechanism & Dose & References \\
\hline 31 & $\begin{array}{l}\text { Chronic corticosterone-induced learning and } \\
\text { memory deficits in rats }\end{array}$ & $\begin{array}{l}\text { Improved memory impairment in the passive avoidance test and reduced the escape latency in the } \\
\text { Morris water maze test. Upregulated the expression of BDNF and CREB. }\end{array}$ & 20,50 , and $100 \mathrm{mg} / \mathrm{kg}$, ip & [75] \\
\hline 32 & AD transgenic mice (APPswe, PSEN1de9) & Inhibited microglial cell activation by regulating the JAK2/STAT3 signaling pathway. & $100 \mathrm{mg} / \mathrm{kg}$, po & [14] \\
\hline 33 & Rats induced with CMS & Increased AMPA receptor expression and decreased neuron apoptosis. & 20 , and $40 \mathrm{mg} / \mathrm{kg}$, po & [76] \\
\hline 34 & Collagenase VII-induced ICH in rats & $\begin{array}{l}\text { Reduced brain edema, inhibited NF- } \mathrm{kB} \text { activation, and suppressed MMP-9 expression. Reduced IL-1 } \beta \\
\text { and IL-6 production, and BBB permeability. }\end{array}$ & 25,50 , and $100 \mathrm{mg} / \mathrm{kg}$, ip & [77] \\
\hline 35 & $\mathrm{~A} \beta$-induced $\mathrm{AD}$ in mice & $\begin{array}{l}\text { Ameliorated memory impairment in the Morris water maze and probe tests. Attenuated glial cell } \\
\text { activations, and increase of TNF- } \alpha \text { and IL-6 expressions. }\end{array}$ & 30,50 , and $100 \mathrm{mg} / \mathrm{kg}$, po & [78] \\
\hline 36 & $\begin{array}{l}\mathrm{A} \beta_{1-42} \text {-induced learning and memory deficits } \\
\text { in rats }\end{array}$ & $\begin{array}{l}\text { Improved learning and memory deficits. Attenuated the hippocampus injury caused by A } \beta \text {. Increased } \\
\text { SOD, catalase, and GSH-px activities and upregulated their gene expression. Increased mitochondrial } \\
\text { membrane potential, and decreased Bax/Bcl-2 ratio, cytochrome c release, and caspase- } 9 /-3 \text { activation. } \\
\text { Activated Nrf2 signaling. }\end{array}$ & 50,100 , and $200 \mathrm{mg} / \mathrm{kg}$, i.p & [79] \\
\hline 37 & $\begin{array}{l}\text { Corticosterone-induced depressive-like } \\
\text { behaviors in mice }\end{array}$ & $\begin{array}{l}\text { Increased sucrose preference and decreased duration of immobility. Downregulated the mRNA and } \\
\text { protein expression of glucocorticoid receptor and BDNF. Upregulated the serum- and SGK1 in the } \\
\text { hippocampus. Increased the expression of } 11 \beta-\mathrm{HSD} 2 \text { protein in the hippocampus. }\end{array}$ & 10 , and $20 \mathrm{mg} / \mathrm{kg}$, po & [80] \\
\hline 38 & $\begin{array}{l}\text { Streptozotocin-induced diabetes-associated } \\
\text { cognitive deficits in rats }\end{array}$ & $\begin{array}{l}\text { Improved memory performances and neuronal survival. Increased ChAT, p-ERK, BDNF, and Bcl-2. } \\
\text { Downregulated the levels of hippocampal AChE, p-JNK, p-p38, caspase-3, Bax, and plasma glucose. }\end{array}$ & 50,100 , and $200 \mathrm{mg} / \mathrm{kg}$, ip & [81] \\
\hline 39 & MCAO-induced ischemia/reperfusion in rats & $\begin{array}{l}\text { Inhibited neuronal apoptosis and enhanced transcription and expression of MCL-1 and BCL-2. } \\
\text { Increased myocardin-related transcription factor-A (MRTF-A) level in ischemic hemisphere. }\end{array}$ & 50,100 , and $200 \mathrm{mg} / \mathrm{kg}$, po & [21] \\
\hline 40 & MCAO-induced reperfusion in mice & $\begin{array}{l}\text { Targeted pathways associated with development, neurophysiological processes, and } \\
\text { cytoskeleton remodeling. }\end{array}$ & $20 \mathrm{mg} / \mathrm{kg}$, iv & [82] \\
\hline 41 & Kainic acid-induced epileptic mice & $\begin{array}{l}\text { Attenuated neuronal damage and apoptosis in the hippocampus. Decreased the expression of miR-497 } \\
\text { and cleaved caspase-3 protein. Upregulated the expression of Bcl-2 protein. }\end{array}$ & $100 \mathrm{mg} / \mathrm{kg}$, ip & [83] \\
\hline 42 & Global cerebral ischemia in gerbils & Improved learning and memory dysfunction by downregulating the phosphorylation level of CaMKII. & $100 \mathrm{mg} / \mathrm{kg}$, ip & [46] \\
\hline 43 & Ketamine-induced toxicity in rats & $\begin{array}{l}\text { Alleviated morphological change and apoptosis. Downregulated caspase-3 activity and caspase-3 } \\
\text { mRNA expression. Inhibited p-Akt and p-GSK-3 } 3 \text { decrease, and relieved p-CREB and BDNF } \\
\text { expression decrease. Increased Bcl-2/Bax and decreased caspase-3 expression. }\end{array}$ & 25,50 , and $100 \mathrm{mg} / \mathrm{kg}$, ip & [16] \\
\hline 44 & Olfactory bulbectomy-induced depression in rats & $\begin{array}{l}\text { Increased the performance in depression-like behavioral tests. Decreased oxidative stress, } \\
\text { synaptophysin expression, and hippocampal apoptosis. Modulated the levels MDA, SOD, and } \\
\text { GSH-Px. Prevented apoptotic protease-activating factor-1 expression. Suppressed caspase-mediated } \\
\text { apoptosis signaling cascades. }\end{array}$ & 20 , and $40 \mathrm{mg} / \mathrm{kg}$, po & [84] \\
\hline
\end{tabular}


Table 2. Cont

\begin{tabular}{|c|c|c|c|c|}
\hline S. No. & Model & Mechanism & Dose & References \\
\hline 45 & In triple-transgenic $(3 \times \mathrm{Tg}-\mathrm{AD})$ mice & $\begin{array}{l}\text { Flavocoxid (a mixture of purified baicalin and catechin) improved learning and memory function. } \\
\text { Decreased eicosanoid production and reduced the phosphorylation level of APP-p-Thr668, p-Thr181 } \\
\text { and p-ERK, and the activation of the NLRP3 inflammasome. }\end{array}$ & $20 \mathrm{mg} / \mathrm{kg}$, ip & [85] \\
\hline 46 & MCAO-induced cerebral ischemia in rats & $\begin{array}{l}\text { Reduced the mortality rates, ameliorated the tissue plasminogen activator-mediated BBB disruption } \\
\text { and hemorrhagic transformation. Scavenged peroxynitrite and inhibited MMP-9 expression. }\end{array}$ & 50,100 , and $150 \mathrm{mg} / \mathrm{kg}$, femoral vein & [86] \\
\hline 47 & $\begin{array}{l}\text { Hyperglycemia-exacerbated MCAO-induced } \\
\text { ischemia/reperfusion in rats }\end{array}$ & Reduced blood glucose, relieved neurological deficit, and decreased infarct volume. & $100 \mathrm{mg} / \mathrm{kg}$ & [13] \\
\hline 48 & CMS-induced rats & $\begin{array}{l}\text { Reversed the changes of depressive-like behavior. Decreased the activation of NLRP3 inflammasome } \\
\text { and IL-1 } \beta \text { and IL-6 levels. }\end{array}$ & 20 and $40 \mathrm{mg} / \mathrm{kg}$ & [10] \\
\hline 49 & MCAO-induced cerebral ischemia in mice & $\begin{array}{l}\text { Reduced the ischemic infarct volume. BA resulted in targeting of pathways related to development, } \\
\text { G-protein signaling, apoptosis, signal transduction, and immunity. }\end{array}$ & $5 \mathrm{mg} / \mathrm{mL}$, iv & [87] \\
\hline 50 & $\begin{array}{l}\text { Subarachnoid hemorrhagic brain injury in mice } \\
\text { via filament perforation }\end{array}$ & $\begin{array}{l}\text { Restored the level of tight junction proteins such as occludin, claudin-5, ZO-1, and collagen IV. } \\
\text { Inhibited the production of IL-1 } \beta \text {, IL-6, and CXCL-3. Attenuated the induction of NOS-2 and NOX-2. }\end{array}$ & $100 \mathrm{mg} / \mathrm{kg}$, ip & [88] \\
\hline 51 & $\begin{array}{l}\text { Left common carotid artery ligation followed by } \\
\text { hypoxia in rats }\end{array}$ & $\begin{array}{l}\text { Reduced cerebral infarct volume and neuronal loss. Inhibited apoptosis, and upregulated the } \\
\text { expression of p-Akt and glutamate transporter } 1 .\end{array}$ & $120 \mathrm{mg} / \mathrm{kg}$, ip & [89] \\
\hline 52 & $\begin{array}{l}\text { Dopamine-induced minimal hepatic } \\
\text { encephalopathy in rats }\end{array}$ & $\begin{array}{l}\text { Reversed the inactivation of the GABA(A)R } \beta / \text { TrkB signaling pathway. Prevented the impairment of } \\
\text { synaptogenesis and improved the memory performance. }\end{array}$ & 20,50 , and $100 \mathrm{mg} / \mathrm{kg}$, ip & [50] \\
\hline 53 & $\begin{array}{l}\text { Chronic corticosterone-induced depression } \\
\text { in mice }\end{array}$ & $\begin{array}{l}\text { Inhibited APPL2-mediated GR hyperactivity and promoted adult neurogenesis. Released depressive } \\
\text { and anxiety symptoms and enhanced olfactory functions. }\end{array}$ & 3.35 and $6.7 \mathrm{mg} / \mathrm{kg}$, po & [90] \\
\hline 54 & $\mathrm{~A} \beta_{1-40}$-induced Alzheimer's disease in rats & $\begin{array}{l}\text { The percentages of astrocytes and neurons were increased. Enhanced the expressions of Nestin and } \\
\text { nucleotide sugar epimerase. }\end{array}$ & $10 \mathrm{mg} / \mathrm{kg}$, ip & [91] \\
\hline 55 & $\begin{array}{l}\text { CMS-induced depressant-like effect in mice } \\
\text { and rats }\end{array}$ & $\begin{array}{l}\text { Reduced immobility time in tail suspension test and the forced swimming test in mice. Decreased } \\
\text { immobility time in forced swimming test in rats. Showed a significant recovery in sucrose intake. } \\
\text { Inhibited monoamine oxidase A and B activity in a dose-dependent manner in rats. }\end{array}$ & $\begin{array}{l}\text { Mice-10, 20, 40, 60, and } 80 \mathrm{mg} / \mathrm{kg} \text {, po } \\
\text { Rats-6.25, 12.5, 25, 50, and } 100 \mathrm{mg} / \mathrm{k} \text {, po }\end{array}$ & [92] \\
\hline 56 & $\begin{array}{l}\text { Chronic corticosterone-induced } \\
\text { anxiety/depression in mice }\end{array}$ & $\begin{array}{l}\text { Alleviated several anxiety/depression-like behaviors. Increased Ki-67- and DCX-positive cells. } \\
\text { Normalized the chronic corticosterone-induced decrease in GR protein levels, the increase in GR } \\
\text { nuclear translocation, and the increase in GR phosphorylation at Ser203 and Ser211. Further, regulated } \\
\text { the level of FK506-binding protein } 51 \text { and phosphorylated serum- and glucocorticoid-inducible kinase } \\
1 \text { at Ser422 and Thr256. }\end{array}$ & 40,80 , and $160 \mathrm{mg} / \mathrm{kg}$, po & [93] \\
\hline
\end{tabular}




\section{Neuroprotective Effects of Baicalin}

\subsection{Alzheimer's Disease Model}

\subsubsection{In Vitro}

The aggregation of $\mathrm{A} \beta$ peptides is an important factor in the etiopathogenesis of $\mathrm{AD}$. Increasing evidence demonstrated that metal ions play a major role in the aggregation of $A \beta$. Hence, inhibition of $A \beta$ aggregation appears as a potential strategy to treat AD. A study reported that baicalin can interact with copper directly and suppress $A \beta_{1-42}$ aggregation. Further, baicalin showed a protective effect against $A \beta_{1-42}$-induced oxidative injuries in SH-SY5Y cells by inhibiting the production of $\mathrm{H}_{2} \mathrm{O}_{2}$ [35]. Xiong et al. [19] determined whether baicalin regulates microglial activation or inhibits inflammatory cytokine production in $\mathrm{A} \beta_{42}$-induced $\mathrm{BV} 2$ cells. The results revealed that baicalin inhibited $A \beta_{42}$-induced BV2 microglial cell proliferation, reduced cluster of differentiation molecule $11 \mathrm{~b}$ (CD11b) expression, decreased the chemotactic ability of BV2 cells. In addition, baicalin effectively inhibited the production of interleukin-6 (IL-6), tumor necrosis factor- $\alpha$ (TNF- $\alpha$ ), and nitric oxide (NO). Furthermore, baicalin pretreatment could significantly downregulate $A \beta$-induced phosphorylation of Janus kinase 2 (JAK2), and signal transducer and activator of transcription 3 (STAT3).

\subsubsection{In Vivo}

A study was conducted to investigate therapeutic effects of a mixture of Chinese herb active components (baicalin, jasminoidin, and cholic acid) against ibotenic acid-induced rats. Pretreatment with the chemical mixture markedly attenuated abnormalities in cognition, brain functional images, and histological morphology in ibotenic acid-induced rats. The chemical mixture significantly influenced on the expression levels of 19 genes in the forebrain. In these, about $60 \%$ of genes were associated with neuroprotection and neurogenesis, and the remaining genes were linked with antioxidation, degradation of proteins, cholesterol metabolism, stress response, and apoptosis. In addition, the treatment increased the expression of these genes with the exception of the apoptosis-related gene [74]. Chen et al. [78] examined the neuroprotective effects of baicalin on pathological changes and behavioral impairments in $A \beta_{1-42}$-induced AD mouse model. Baicalin could ameliorate memory impairment in the Morris water maze and probe tests. Further, baicalin treatment attenuated glial cell activation and decreased the expression of TNF- $\alpha$ and IL- 6 in A $\beta_{1-42}$-induced AD mice.

In A $\beta$-induced AD transgenic mice, baicalin significantly regulated the JAK2/STAT3 signaling pathway [14]. In an $A \beta$ toxicity rat model of $A D$, baicalin treatment improved learning and memory deficits in Morris water maze test, and attenuated the hippocampus injury. Baicalin treatment significantly increased the level of antioxidant enzymes and their gene expressions, such as superoxide dismutase (SOD), catalase, and glutathione peroxidase (GSH-Px). In addition, baicalin increased mitochondrial membrane potential and reduced Bax/B cell lymphoma 2 family (Bcl-2) ratio, cytochrome c release, and caspase- $9 /-3$ activation in $A \beta$-induced rats. Further, the antioxidative effect of baicalin may associate with the activation of nuclear factor erythroid 2-related factor 2 (Nrf2) signaling pathway [79]. Bitto et al. [85] investigated the neuroprotective effect of flavocoxid (a mixture of purified baicalin and catechin) in triple-transgenic (3xTg-AD) mice. Flavocoxid is a dual inhibitor of cyclooxygenases-1/2 (COX-1/2) and 5-lipoxygenase (5-LOX). Flavocoxid treatment improved learning and memory function, and decreased the production of eicosanoid. In addition, flavocoxid downregulated the activation of nucleotide-binding domain and leucine-rich repeat protein-3 (NLRP3) inflammasome and IL-1 $\beta$ production. Furthermore, flavocoxid reduced the phosphorylation level of the amyloid precursor protein (APP-p-Thr668), p-tau (p-Thr181) and extracellular signal-regulated kinases 1 and 2 (p-ERK1/2). A recent study demonstrated that baicalin increased the percentages of astrocytes and neuronal in $A \beta_{1-40}$-induced rats. Moreover, baicalin treatment enhanced expressions of Nestin and nucleotide sugar epimerase [91]. 


\subsection{Parkinson's Disease Model}

In Vivo

1-Methyl-4-phenyl-1,2,3,6-tetrahydropyridine (MPTP) is a potent and selective nigrostriatal dopaminergic neurotoxin that produces many of the neuropathological characteristics of idiopathic PD. In MPTP-induced mice, baicalin treatment effectively prevented the loss of tyrosine hydroxylase (TH)-positive neurons in substantia nigra, and increased the dopamine content of striatum. In addition, baicalin significantly increased glutathione content (GSH) in the brain [57]. Previous studies reported that iron accumulates in the substantia nigra of patients with PD. Xiong et al. [69] found that baicalin treatment markedly inhibited iron accumulation in different brain regions, and showed a protective effect on dopaminergic neurons in rotenone-induced rats.

\subsection{Ischemia}

\subsubsection{In Vitro}

Ischemic stroke is the third most common cause of death worldwide in adults. According to the World Health Organization, 5-6 million individuals die from stroke each year [9]. OGD is a widely used in vitro model to study ischemic stroke. Liu et al. [30] investigated the effect of baicalin on ischemic-like or excitotoxic injury, and protein kinase $C$ alpha $(\mathrm{PKC}(\alpha))$ activation in rat hippocampal slices. In OGD- and N-methyl-D-aspartate (NMDA)-induced rat hippocampal slices, baicalin ameliorated viability reduction and inhibited the increased membrane portion of $\operatorname{PKC}(\alpha)$. It was reported that the activation of 5-LOX is involved in ischemic neuronal damage. Baicalin showed the protective effect against OGD-induced ischemic-like injury in rat cortical neurons by partly inhibiting NMDA receptor-mediated 5-LOX activation [31]. Jung et al. [32] found that baicalin attenuated the negative insult of light, hydrogen peroxide, and serum withdrawal to RGC-5 cells.

Nucleotide-binding oligomerization domain protein 2 (NOD2) receptor plays a key role in innate immunity, and is genetically associated with various inflammatory reactions. In this context, the effect of baicalin on NOD2/TNF $\alpha$ in OGD-induced BV2 cells, PC12 cells, and primary neuron cells was investigated. The results indicated that baicalin treatment could effectively suppress the expression of NOD2 and TNF $\alpha$ in mRNA as well as protein levels [34]. In OGD-induced microglial cells, baicalin markedly inhibited the release of TNF- $\alpha$, IL-1 $\beta$, IL- 6 , and IL- 8 , and reduced Toll-like receptor 4 (TLR4) mRNA expression and tumor necrosis factor receptor-associated factor 6 (TRAF6) levels. Additionally, baicalin downregulated nuclear factor of kappa light polypeptide gene enhancer in B-cells inhibitor-alpha (IkB- $\alpha$ ), c-jun, ERK1/2, c-Jun N-terminal kinase (JNK), and p38 phosphorylation, and inhibited the transfer of myeloid differentiation primary response 88 (MyD88) from cytoplasm to membrane in OGD-induced microglial cells [36].

In another study, baicalin effectively protected neurons against $\mathrm{H}_{2} \mathrm{O}_{2}$-induced injury and improved the SOD activity [38]. Baicalin also showed the neuroprotective effect against extraneous and endogenous peroxynitrite-induced toxicity in SH-SY5Y cells [40]. Zhang et al. [41] examined the protective effect of baicalin on OGD-induced brain microvascular endothelial cells through anti-inflammation. The results showed that baicalin increased cell viability, and decreased lactate dehydrogenase (LDH) leakage rate, TNF- $\alpha$, IL-1 $\beta$, and IL-6 levels in the culture media. In addition, baicalin markedly downregulated the phosphorylation of proteins in mitogen-activated protein kinase (MAPK) signaling pathways, such as p-MRK1/2, p-ERK, and p-p38. Further, baicalin significantly downregulated the phosphorylation of proteins in nuclear factor kappa B (NF- $\kappa \mathrm{B})$ signaling pathway, such as phosphorylated-IкB kinase $\alpha$ and $\beta$ (p-IKK $\alpha$ and $p-I K K \beta)$, and $p-I \kappa B \alpha$. Moreover, baicalin

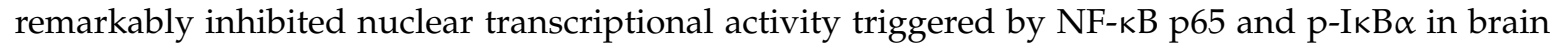
microvascular endothelial cells. On the basis of these findings, authors suggested that baicalin exhibited its neuroprotective effect by downregulating the MAPK and NF-kB signaling pathway. 
In $\mathrm{H}_{2} \mathrm{O}_{2}$-induced rat primary cortical neurons, baicalin effectively inhibited neuronal apoptosis by enhancing transcription and expression of myeloid cell leukemia-1 (MCL-1) and BCL-2. Additionally, baicalin remarkably increased myocardin-related transcription factor-A (MRTF-A) level. However, the anti-apoptosis effect of baicalin was significantly abrogated by the transfection of small interfering RNA of MRTF-A (MRTF-A siRNA) in primary cortical neuron cultures. Baicalin also increased the transactivity of MCL-1 and BCL-2 promoter by activating the key CarG box (CC [A/T] 6GG) element. Moreover, baicalin-induced MRTF-A expression and transactivity and expression of MCL-1 and BCL-2 were reduced by phosphatidylinositol-3 kinase (PI3K) inhibitor, LY294002, and ERK1/2 inhibitor, PD98059 [21]. Another study indicated that baicalin showed neuroprotective effects against hypoxia and OGD/reoxygenation (RO)-induced injury in SH-SY5Y cells. Baicalin significantly attenuated OGD/RO-induced apoptotic cell death in SH-SY5Y cells, and decreased caspase-3 expression. In addition, baicalin markedly downregulated NF- $\mathrm{kB}$ and N-methyl-D-aspartic acid receptor-1 (NMDAR1) in OGD/RO-induced cells [45].

A recent study reported that baicalin treatment suppressed dynamin-related protein 1 (Drp-1) expression, reduced mitochondrial fission, elevated mitofusin-2 (MFN2) generation, upregulated Drp-1 Ser637 phosphorylation, and increased mitochondrial membrane potential in OGD/reperfusioninduced PC12 cells via the inhibition of reactive oxygen species (ROS) production. In addition, baicalin attenuated cell apoptosis and increased mitophagy [13]. Luo et al. [48] evaluated the protective effect of baicalin against OGD-induced ischemic injury in endothelial cells. The authors found that baicalin effectively inhibited cell death, decreased cell membrane damage, and maintained the integrity of the nucleus. Baicalin treatment also decreased necroptosis ratio and regulated the expression of RIP-1 and RIP-3 in bEnd. 3 cells. Furthermore, baicalin inhibited the production of ROS and malondialdehyde (MDA), and increased SOD activity in OGD-induced bEnd.3 cells.

\subsubsection{In Vivo}

A number of researchers have used middle cerebral artery occlusion (permanent or transient) to study focal cerebral ischemia in mice or rats. A study indicated that that baicalin treatment reduced MCAO-induced neuronal damage, brain edema, and blood-brain barrier (BBB) permeability by inhibiting the expression of matrix metallopeptidase 9 (MMP-9) and MMP-9-mediated occludin degradation [63]. Baicalin also showed a protective effect against MCAO-induced cerebral ischemia in rat by reducing the expression of TLR2/4, NF- $\mathrm{KB}$, inducible nitric oxide synthase (iNOS), and COX-2. In addition, baicalin administration decreased the serum content of TNF- $\alpha$ and IL-1 $\beta$ [64]. In another study, baicalin markedly reduced the enzymatic activity of myeloperoxidase (MPO) and downregulated the expression of iNOS and COX-2 mRNAs, and cleaved caspase-3 protein in MCAO-induced rats [59]. In addition, baicalin downregulated the expression of NOD2 and TNF $\alpha$ proteins in bilateral common carotid artery ligation (BCCL)-induced mice [34]. Xue et al. [61] found that baicalin treatment decreased the level of NF- $\mathrm{kB}$ p65 in MCAO-induced focal cerebral ischemia in rats. In gerbils with transient global cerebral ischemic/reperfusion injury, the administration of baicalin significantly attenuated ischemia-induced neuronal cell damage in gerbils. In addition, baicalin reduced the level of MDA, and increased SOD, GSH, and GSH-Px activities. Moreover, baicalin markedly upregulated the expression of BDNF and suppressed the expression of caspase- 3 at mRNA and protein levels [62].

Zhang et al. [55] compared the individual and combined effects of baicalin with jasminoidin on cerebral ischemia/reperfusion injury in rats. When compared with individual treatment, the combined treatment significantly ameliorated the results of 2,3,5-triphenyltetrazolium chloride (TTC) and histological examination. In addition, this combination ameliorated diffusion weighted imaging (DWI) of magnetic resonance imaging (MRI) and promoted brain-derived neurotrophic factor (BDNF) expression and inhibited caspase-3 expression. The capillary electrophoresis-laser-induced fluorescence detection technique was used to investigate the effect of baicalin on changes of amino acid neurotransmitters level during cerebral ischemia in rats. In the results, concentrations of Glu, Asp, 
gamma-aminobutyric acid (GABA), and Gly in the brain cortex were elevated due to cerebral ischemia. However, baicalin treatment could attenuate the elevations of Glu and Asp in the cerebral cortex [51]. A study also attempted to investigate and determine the effect of baicalin on different protein expression modes in MCAO-induced mice brains. However, there was no significant difference in the expression of twenty-four proteins between baicalin-treated MCAO group and the sham-operation group [60].

In ischemia/reperfusion to the rat retina, baicalin treatment regulated the localization of Thy-1 and choline acetyltransferase (ChAT) level, and the level of various proteins and mRNAs in the retina. However, baicalin treatment did not affect the level of caspase- 8 and caspase- 3 mRNAs caused by ischemia/reperfusion [32]. Chang et al. [56] examined the prophylactic effect of baicalin in an animal model of heatstroke. Baicalin administration effectively attenuated the hyperthermia, intracranial hypertension, and increased $\mathrm{NO}_{2}{ }^{-}$, glutamate, glycerol, lactate/pyruvate ratio, and dihydroxybenzoic acid levels in the hypothalamus of heatstroke-induced rats. Further, baicalin markedly decreased the levels of IL- $1 \beta$ and TNF- $\alpha$ in the serum, as well as the hypothalamus.

In intracerebral hemorrhage (ICH)-induced rats, baicalin significantly attenuated brain edema, inhibited cell apoptosis, and suppressed the expression of brain protease-activated receptor-1 (PAR-1) at both the mRNA and protein levels [70]. Baicalin could also improve neurological function and decrease brain infarction in MCAO-induced rats. Further, baicalin reduced cell apoptosis and the production of ROS and MDA. Moreover, baicalin interfered with SOD and nicotinamide adenine dinucleotide 2'-phosphate oxidase (NOX) activities [38]. Dai et al. [71] investigated the effect of baicalin on global ischemia-induced gerbils, and found that baicalin treatment effectively facilitated neurological function and attenuated the ischemia-induced neuronal damage. Additionally, baicalin administration increased the expression of $\mathrm{GABA}_{\mathrm{A}}$ receptor $(\mathrm{GABA}(\mathrm{A}) \mathrm{R}) \alpha 1, \mathrm{GABA}(\mathrm{A}) \mathrm{R} \gamma 2$, and $\mathrm{K}-\mathrm{Cl}$ co-transporter 2 (KCC2), and decreased the expression of $\mathrm{Na}-\mathrm{K}-\mathrm{Cl}$ cotransporter 1 (NKCC1) in the hippocampus of gerbils following an ischemic insult. Moreover, baicalin treatment markedly increased the protein expressions of HSP70 and phosphorylated ERK (p-ERK), and decreased the expression of phosphorylated JNK (p-JNK) and phosphorylated p38 (p-p38) in ischemic gerbils. Baicalin also inhibited 3-nitrotyrosine formation, decreased infarct size, and attenuated apoptotic cell death in ischemia/reperfusion-induced injury in rat brain [40].

A study reported that baicalin treatment increased the number of newly generated cells in the hippocampus of rats exposed to transient cerebral ischemia. Additionally, baicalin improved cognitive impairment as measured in the Morris water maze test [42]. In a rat model of collagenase VII-induced $\mathrm{ICH}$, baicalin administration reduced brain edema, inhibited NF- $\mathrm{kB}$ activation, and suppressed MMP-9 expression. In addition, baicalin reduced the production of IL-1 $\beta$ and IL-6, as well as BBB permeability [77]. Baicalin effectively inhibited neuronal apoptosis by enhancing the transcription and expression of MCL-1 and BCL-2 in MCAO-induced rats. In addition, baicalin administration increased MRTF-A level in ischemic hemisphere [21]. Baicalin also improved learning and memory dysfunction in global cerebral ischemia/reperfusion-induced gerbils by downregulating the phosphorylation level of $\mathrm{Ca}^{2+} /$ calmodulin-dependent protein kinase II (CaMKII) and preventing hippocampal neuronal apoptosis [46]. In a recent study, baicalin administration significantly decreased the mortality rates, and ameliorated BBB disruption and hemorrhagic transformation. In addition, baicalin markedly scavenged peroxynitrite and inhibited MMP-9 expression and activity in MCAO-induced ischemic brains with delayed tissue plasminogen activator treatment [86]. The effect of baicalin on hyperglycemia-exacerbated cerebral ischemia/reperfusion injury in rats was investigated by Li et al. [13]. In their study, baicalin treatment decreased blood glucose, alleviated neurological deficit and reduced infarct volume.

Inflammatory responses and blood-brain barrier disruption play a critical role in the formation of edema during subarachnoid hemorrhagic brain injury. The protective effect of baicalin against filament perforation-induced subarachnoid hemorrhagic brain injury in mice was investigated by Shi et al. [88]. Baicalin administration effectively increased neurological score and brain water content. 
Baicalin also restored levels of tight junction proteins, such as survivin, claudin-5, zonula occludens-1 (ZO-1), and collagen IV. In addition, baicalin treatment inhibited the production of IL-1 $\beta$, IL-6, and chemokine (C-X-C motif) ligand 3 (CXCL-3) in subarachnoid hemorrhage mice. Furthermore, baicalin downregulated the mRNA and protein levels of NOS-2 and NOX-2 in subarachnoid hemorrhage mice. Recently, the neuroprotective effect of baicalin in a rat model of hypoxic-ischemic encephalopathy was investigated. In the results, baicalin markedly reduced apoptosis and increased the expression of phosphorylated protein kinase B (p-Akt) and glutamate transporter 1. Further, the PI3K/Akt inhibitor, LY294002 blocked the effect of baicalin on p-Akt and glutamate transporter 1 [89].

\subsection{Neuroprotective and Cognitive Enhancement Effects}

\subsubsection{In Vitro}

Ketamine is extensively used as an anesthetic in pediatric clinical practice. However, a number of studies have demonstrated that exposure to ketamine during the developmental period induces neuronal toxicity. In vitro experiments showed that baicalin attenuated ketamine-induced cell viability decrease, morphological change, and caspase- 3 expression activation in the primary neuron-glia mixed cultures. Further, the results demonstrated that baicalin showed the neuroprotective effect against ketamine-induced toxicity by activating PI3K/Akt and its downstream cAMP response element-binding protein (CREB)/BDNF/Bcl-2 signaling pathways [16]. Baicalin also suppressed co-listin sulfate-induced neuronal apoptosis in PC12 cells by inhibiting free radical injury, and downregulating caspase-3 and lactate dehydrogenase activities [39]. Additionally, baicalin showed a potent neuroprotective effect against $\mathrm{H}_{2} \mathrm{O}_{2}$-induced toxicity in PC12 cells. Baicalin pretreatment of PC12 cells reduced the viability loss and apoptotic rate in $\mathrm{H}_{2} \mathrm{O}_{2}$-induced $\mathrm{PC} 12$ cells. In addition, baicalin increased SOD, GSH-Px activities and decreased the level of MDA. Moreover, baicalin upregulated the expression of survivin, Bcl-2, and p-STAT3, and downregulated the expression of caspase-3 expression [15]. In thrombin-induced injury in SH-SY5Y cells, baicalin reduced cell death by inhibiting NF- $\mathrm{kB}$ activation and suppressing the expression of PAR-1 and caspase-3 [12].

Prolyl oligopeptidase (POP) is a cytosolic serine peptidase that has been related to schizophrenia, bipolar affective disorder, and associated neuropsychiatric disorders. An in vitro study demonstrated that baicalin inhibited the generation of prolyl oligopeptidase in a dose-dependent manner [33]. STAT3 and basic helix-loop-helix (bHLH) gene family are main cellular signaling molecules to regulate cell fate decision and neuronal differentiation of neural stem/progenitor cells (NSPCs). In this context, Li et al. [37] examined the effects of baicalin on stat 3 phosphorylation, the expression of bHLH family proteins, and neuronal differentiation of NSPCs. In their study, baicalin treatment promoted the number of microtubule-associated protein (MAP-2) positive-staining cells, and reduced glial fibrillary acidic protein (GFAP)-staining cells. Additionally, baicalin suppressed the expression of $\mathrm{p}$-stat 3 and Hes1, and upregulated the expression of NeuroD1 and Mash1.

In another study, Morita et al. [44] determined whether baicalin promotes neuronal differentiation in human iPS cells, and the expression of bHLH gene during neuronal differentiation. The results demonstrated that baicalin can influence the neuronal fate decision in human iPS cells by promoting neuronal differentiation and inhibiting glial differentiation. In addition, baicalin treatment decreased the level of Hes1 protein and upregulated the expression of Ascl1 gene. The proliferation and migration of Schwann cells (SCs) are important events in the process of peripheral nerve repair. A recent study indicated that baicalin could promote the viability of RSC96 SCs and exhibit the greatest gene expression of neurotrophic factors, such as glial cell-derived neurotrophic factor (GDNF), BDNF, and ciliary neurotrophic factor (CNTF). These neurotrophic factors are considered essential factors in the process of never cell regeneration [49]. 


\subsubsection{In Vivo}

In rats with spinal cord injury (SCI), $\mathrm{BC}$ treatment remarkably decreased the water content of spinal cord tissue, the permeability of blood-spinal cord barrier, and oxidant stress. Further, baicalin decreased the expression of TNF- $\alpha$, NF- $\mathrm{kB}, \mathrm{Bax}, \mathrm{Bcl}-2$, and caspase-3 [20]. Baicalin exhibited a strong neuroprotective activity against ketamine-induced apoptotic neurotoxicity in rat pups. Baicalin treatment increased the expression of $\mathrm{p}$-Akt, phosphorylated-glycogen synthase kinase-3 beta (p-GSK-3 $\beta$ ), p-CREB, and BDNF in ketamine-induced rats. In addition, baicalin increased the expression of bcl-2/Bax and decreased the expression of caspase-3 in ketamine-induced rats [16]. The administration of baicalin also enhanced memory impairment as measured in the passive avoidance Morris water maze tests in corticosterone-induced rats. Additionally, the administration of baicalin effectively alleviated memory-related decreases in the expression levels of BDNF and CREB in the hippocampus [75]. Ma et al. [81] found that baicalin exhibited a strong protective activity against streptozotocin-induced diabetes-associated cognitive deficits in rats. The results revealed that baicalin treatment improved memory performances and increased the neuronal survival in streptozotocin-induced rats. Baicalin treatment also increased ChAT, p-ERK, BDNF, and Bcl-2. Furthermore, baicalin decreased the levels of hippocampal acetylcholinesterase (AchE), p-JNK, p-p38, caspase-3, Bax, and plasma glucose.

\subsection{Epilepsy: In Vivo}

Oxidative stress can markedly alter neuronal function, and has been associated with status epilepticus. Liu et al. [67] investigated whether baicalin could exhibit anticonvulsant and neuroprotective effects in pilocarpine-induced epileptic rats. Baicalin treatment remarkably postponed the onset of the first limbic seizures and status epilepticus, reduced the mortality rate, and decreased the changes in the levels of lipid peroxidation, and nitrite and reduced glutathione contents in the hippocampus. Moreover, baicalin attenuated the neuronal cell damage, apoptosis, and degeneration in pilocarpine-induced seizures in the hippocampus of rats. In kainic acid-induced epileptic mice, baicalin administration effectively attenuated neuronal injury and apoptosis in the hippocampus. Further, baicalin decreased the expression of miR-497 and cleaved caspase-3 protein, and upregulated the expression of Bcl-2 protein [83].

\subsection{Antidepressant Effect: In Vivo}

In depressive disorders, the regulation of $\alpha$-amino-3-hydroxy-5-methyl-4-isoxazolepropionic acid (AMPA) receptor expression plays a key role in the viability of neurons and the level of BDNF in the brain. In chronic unpredictable mild stress (CMS)-induced rats, baicalin administration significantly increased AMPA receptor expression and decreased neuron apoptosis [76]. A study was also carried out to investigate the effect of baicalin on CMS-treated rats. The results demonstrated that baicalin effectively reversed the changes in depressive-like behaviors, such as decreased sucrose intake and locomotor activity, and increased immobility time. In addition, baicalin treatment significantly decreased the activation of NLRP3 inflammasome and the levels of IL-1 $\beta$ and IL- 6 in rat prefrontal cortex [10]. Baicalin treatment also increased the sucrose preference, decreased serum corticosterone levels, downregulated the activity and expression of COX-2 mRNA, and decreased the level of prostaglandin E2 (PGE2) in CMS-induced rats [73].

In corticosterone-induced mice, baicalin treatment relieved depressive-like behaviors, including the increased sucrose preference and decreased the duration of immobility. In addition, baicalin restored the level of serum corticosterone, upregulated the expression of glucocorticoid receptor and BDNF, as well as downregulated serum- and glucocorticoid-regulated kinase 1 (SGK1) in the hippocampus. Furthermore, baicalin markedly increased the expression of $11 \beta$-hydroxysteroid dehydrogenase-2 (11 $\beta$-HSD2) protein in the hippocampus [80]. A recent study also demonstrated that baicalin inhibited adaptor protein, phosphotyrosine, interacting with $\mathrm{PH}$ domain and leucine zipper 2 
(APPL2)-mediated glucocorticoid receptor (GR) hyperactivity, promoted adult neurogenesis, released depressive and anxiety symptoms, and enhanced olfactory functions in chronic corticosterone-induced mice [90]. In a rat model of olfactory bulbectomy-induced depression, Yu et al. [84] found that baicalin effectively increased the performance in depression-like behavioral tests, and decreased oxidative stress, synaptophysin expression, and hippocampal apoptosis. Further, baicalin regulated the levels or activity of MDA, SOD, and GSH-Px. Moreover, baicalin treatment prevented apoptotic PAR-1 expression and suppressed caspase-mediated apoptosis signaling cascades in olfactory bulbectomy-induced rats. In another study, baicalin improved antidepressant-like behaviors in mice and rats. Additionally, oral administration of baicalin effectively inhibited monoamine oxidase A and B activity in rats. Furthermore, baicalin showed a significant recovery in sucrose intake in CMS-induced rats [92]. Zhang et al. [93] found that baicalin treatment improved anxiety/depression-like behaviors and promotes hippocampal neurogenesis in chronic corticosterone-induced mice. Further, baicalin may normalize GR function through serum- and glucocorticoid-inducible kinase 1- and FK506-binding protein 51-mediated GR phosphorylation.

\subsection{Anxiolytic-Like Effect: In Vivo}

Liao et al. [51] found that the anxiolytic-like effect of baicalin may be mediated through the activation of benzodiazepine binding site of GABA(A) receptors. The anxiolytic effects of baicalin alone, and in combination with other anxiolytics in mice, were investigated by $\mathrm{Xu}$ et al. [54]. Baicalin treatment showed significant anxiolytic-like effects as measured in the elevated plus-maze test. Co-administration of baicalin with DL-tetrahydropalmatine also exhibited a considerable anxiolytic-like effect. In mice with picrotoxin-induced seizure, Wang et al. [58] suggested that baicalin administration showed anxiolytic-like effects through the alpha2- and alpha3-containing GABA(A) subtypes.

\subsection{Blood-Brain Barrier Penetrating Ability}

The BBB is a highly selective semipermeable membrane barrier, plays an important role in maintaining homeostasis of the CNS. It protects the brain by blocking the passage of medications into the brain. Hence, BBB-penetrating ability is a prerequisite for medications used for the treatment of various brain disorders [45]. Zhang et al. [94] investigated the effect of baicalin on the transport of nimodipine (a dihydropyridine calcium channel blocker) across the BBB. In their study, baicalin (at $2-5 \mu \mathrm{g} / \mathrm{mL}$ ) increased the uptake of nimodipine, whereas baicalin (at 10-20 $\mu \mathrm{g} / \mathrm{mL}$ ) decreased the uptake of nimodipine in rat brain microvascular endothelial cell culture. Liu et al. $[95,96]$ developed a novel brain-targeting drug delivery system based on baicalin-loaded PEGylated cationic solid lipid nanoparticles modified by OX26 antibody (OX26-PEG-CSLN) and demonstrated that OX26-PEG-CSLN improved the uptake of baicalin across the BBB, and enhanced the bioavailability of baicalin in cerebral spinal fluid of rats with cerebral ischemia/reperfusion injury.

Another study demonstrated that intranasal administration of baicalin, about $52.36-100 \%$ baicalin content at $8 \mathrm{~h}$, was transported to the brain through the olfactory pathway [97]. Zhang et al. [98] also investigated the pharmacokinetic process of baicalin in normal rat blood, as well as cerebral nuclei, such as cortex, hippocampus, striatum, thalamus, and brain stem. Yang et al. [99] examined the role of Panax notoginsenosides in the pharmacokinetic behavior of baicalin in rat brain. The data indicated that Panax notoginsenosides decreased the elimination rate of baicalin from rat plasma and promoted the penetration of baicalin into rat brain. Additionally, Panax notoginsenosides increased the concentration and reduced the elimination of baicalin from rat brain. A recent study also demonstrated that six Radix scutellariae flavones such as baicalein, wogonin, oroxylin A, baicalin, wogonoside, and oroxyloside could cross the blood-brain barrier, with brain concentrations ranging from 7.9 to $224.0 \mathrm{pmol} / \mathrm{g}[100]$. 


\section{Conclusions and Future Perspectives}

S. baicalensis has been traditionally used for the treatment of a variety of disorders since ancient times. Baicalin is the main bioactive component from the root of S. baicalensis. The present review summarizes the protective effects of baicalin for the treatment of neurotoxicity-related diseases such as ischemic stroke, AD, and PD. In addition, baicalin exhibits considerable anxiolytic-like and antidepressant effects. In the mechanistic aspects, baicalin shows a strong protective activity against neurotoxicity-mediated disorders by regulating different cell signaling pathways. The published reports reveal that baicalin has antioxidant, anti-inflammatory, anti-apoptotic, and anti-excitotoxicity properties. Interestingly, baicalin promotes neurogenesis and cell differentiation. Baicalin may be a potential candidate for the prevention and treatment of various neurodegenerative diseases and enhancement of cognitive functions due to its multitargeted actions and BBB-penetrating ability. Although baicalin showed potent neuroprotective effects under in vitro and in vivo models, clinical studies in association with baicalin against these diseases are meager. Further studies in relation to safety profiles of baicalin, improvement of its bioavailability and clinical trials are needed.

Author Contributions: K.S. wrote the manuscript; P.D. and M.K. conducted the literature review; S.J.P. and S.K. corrected and revised the manuscript.

Acknowledgments: This work was supported by Korea Institute of Planning and Evaluation for Technology in Food, Agriculture, Forestry and Fisheries (IPET) through High Value-added Food Technology Development Program, funded by Ministry of Agriculture, Food and Rural Affairs (MAFRA) (317044-03) and the research grant from Kangwon National University, Chuncheon, Republic of Korea.

Conflicts of Interest: The authors declare no conflict of interest.

\section{Abbreviations}

11ß-HSD2

5-LOX

AchE

AD

Akt

AMPA

APP

APPL2

$\mathrm{A} \beta$

BBB

BCCA

BCCL

Bcl-2

BDNF

bHLH

CaMKII

CD11b

ChAT

CMS

CNS

CNTF

COX-1/2

CREB

CXCL3

Drp-1

DWI

ERK1/2

GABA(A)R
$11 \beta$-hydroxysteroid dehydrogenase- 2

5-lipoxygenase (5-LOX)

acetylcholinesterase

Alzheimer's disease

protein kinase B

$\alpha$-amino-3-hydroxy-5-methyl-4-isoxazolepropionic acid

amyloid precursor protein

adaptor protein, phosphotyrosine interacting with $\mathrm{PH}$ domain and leucine zipper 2

amyloid- $\beta$

blood-brain barrier

bilateral common carotid artery

bilateral common carotid artery ligation

B cell lymphoma 2 family

brain-derived neurotrophic factor

basic helix-loop-helix

$\mathrm{Ca}^{2+} /$ calmodulin-dependent protein kinase II

cluster of differentiation molecule $11 \mathrm{~b}$

choline acetyltransferase

chronic mild stress

central nervous system

ciliary neurotrophic factor

cyclooxygenases-1/2

cAMP response element-binding protein

chemokine (C-X-C motif) ligand 3 (CXCL-3)

dynamin-related protein 1

diffusion weighted imaging

extracellular signal-regulated kinases 1 and 2

$\mathrm{GABA}_{\mathrm{A}}$ receptor 


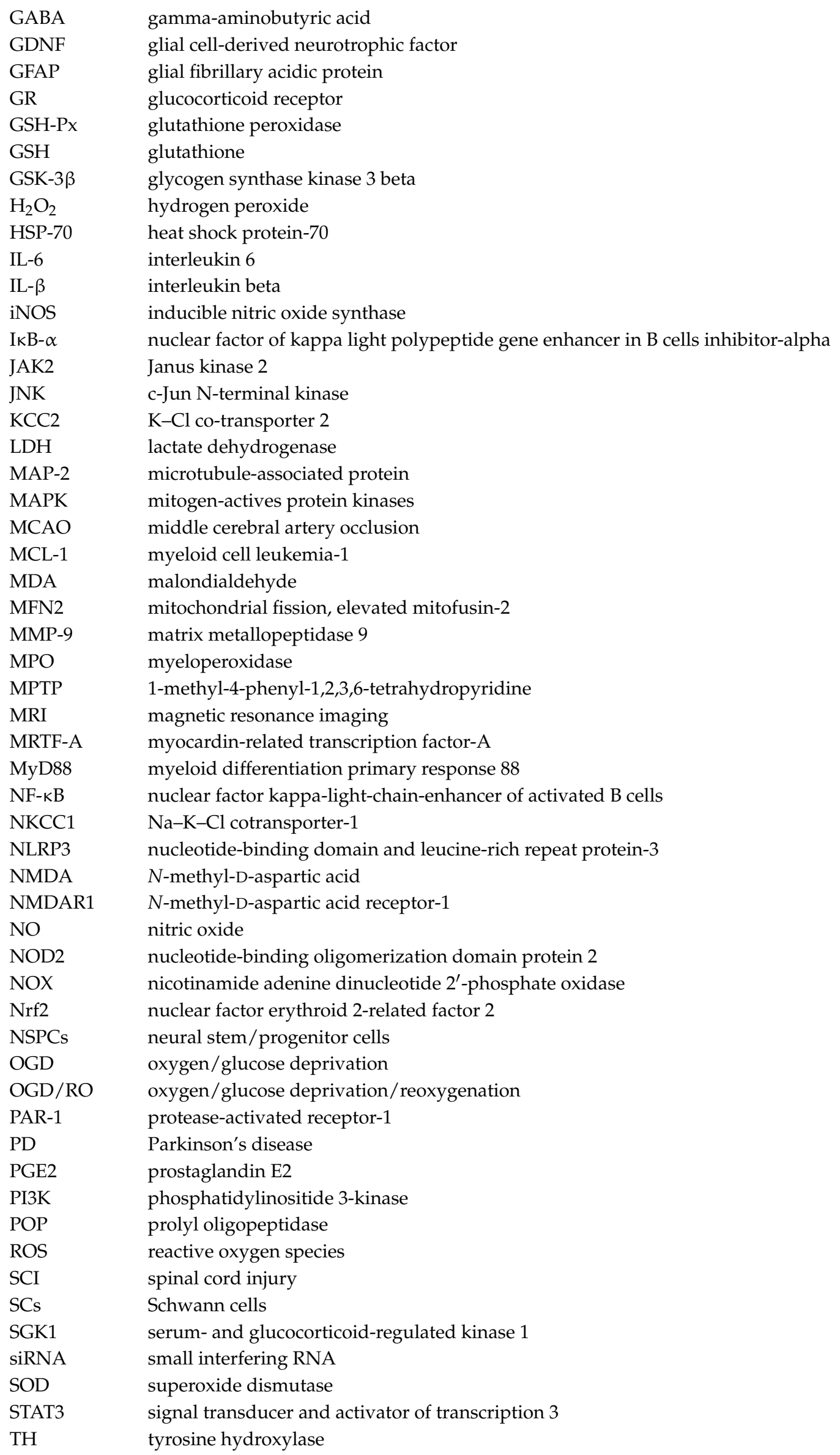


TLR4 Toll like receptor-4

TNF- $\alpha$ tumor necrosis factor alpha

TRAF6 tumor necrosis factor receptor-associated factor 6

TRkB tropomyosin receptor kinase B

TTC 2,3,5-triphenyltetrazolium chloride

ZO-1 zonula occludens-1.

\section{References}

1. Zhao, Q.; Chen, X.Y.; Martin, C. Scutellaria baicalensis, the golden herb from the garden of Chinese medicinal plants. Sci. Bull. (Beijing) 2016, 6, 1391-1398. [CrossRef] [PubMed]

2. Shang, X.; He, X.; He, X.; Li, M.; Zhang, R.; Fan, P.; Zhang, Q.; Jia, Z. The genus Scutellaria an ethnopharmacological and phytochemical review. J. Ethnopharmacol. 2010, 128, 279-313. [CrossRef] [PubMed]

3. Gaire, B.P.; Moon, S.K.; Kim, H. Scutellaria baicalensis in stroke management: Nature's blessing in traditional Eastern medicine. Chin. J. Integr. Med. 2014, 20, 712-720. [CrossRef] [PubMed]

4. Ishimaru, K.; Nishikawa, K.; Omoto, T.; Asai, I.; Yoshihira, K.; Shimomura, K. Two flavone 21-glucosides from Scutellaria baicalensis. Phytochemistry 1995, 40, 279-281. [CrossRef]

5. Noh, K.; Kang, Y.; Nepal, M.R.; Jeong, K.S.; Oh, D.G.; Kang, M.J.; Lee, S.; Kang, W.; Jeong, H.G.; Jeong, T.C. Role of intestinal microbiota in baicalin-induced drug interaction and its pharmacokinetics. Molecules 2016, 21, 337. [CrossRef] [PubMed]

6. Zheljazkov, V.D.; Cantrell, C.L.; Ebelhar, M.W.; Coker, C.; Evans, W.B. Quality assessment and yield of baikal skullcap (Scutellaria baicalensis) grown at multiple locations. HortScience 2007, 42, 1183-1187.

7. Bochoráková, H.; Paulová, H.; Slanina, J.; Musil, P.; Táborská, E. Main flavonoids in the root of Scutellaria baicalensis cultivated in Europe and their comparative antiradical properties. Phytother. Res. 2003, 17, 640-644. [CrossRef] [PubMed]

8. Dinda, B.; Dinda, S.; DasSharma, S.; Banik, R.; Chakraborty, A.; Dinda, M. Therapeutic potentials of baicalin and its aglycone, baicalein against inflammatory disorders. Eur. J. Med. Chem. 2017, 131, 68-80. [CrossRef] [PubMed]

9. Liang, W.; Huang, X.; Chen, W. The effects of baicalin and baicalein on cerebral ischemia: A review. Aging Dis. 2017, 8, 850-867. [CrossRef] [PubMed]

10. Liu, X.; Liu, C. Baicalin ameliorates chronic unpredictable mild stress-induced depressive behavior: Involving the inhibition of NLRP3 inflammasome activation in rat prefrontal cortex. Int. Immunopharmacol. 2017, 48, 30-34. [CrossRef] [PubMed]

11. Gasiorowski, K.; Lamer-Zarawska, E.; Leszek, J.; Parvathaneni, K.; Yendluri, B.B.; Błach-Olszewska, Z.; Aliev, G. Flavones from root of Scutellaria baicalensis Georgi: Drugs of the future in neurodegeneration? CNS Neurol. Disord. Drug Targets 2011, 10, 184-191. [CrossRef] [PubMed]

12. Ju, X.N.; Mu, W.N.; Liu, Y.T.; Wang, M.H.; Kong, F.; Sun, C.; Zhou, Q.B. Baicalin protects against thrombin induced cell injury in SH-SY5Y cells. Int. J. Clin. Exp. Pathol. 2015, 8, 14021-14027. [PubMed]

13. Li, S.; Sun, X.; Xu, L.; Sun, R.; Ma, Z.; Deng, X.; Liu, B.; Fu, Q.; Qu, R.; Ma, S. Baicalin attenuates in vivo and in vitro hyperglycemia-exacerbated ischemia/reperfusion injury by regulating mitochondrial function in a manner dependent on AMPK. Eur. J. Pharmacol. 2017, 815, 118-126. [CrossRef] [PubMed]

14. Xiong, J.; Wang, C.; Chen, H.; Hu, Y.; Tian, L.; Pan, J.; Geng, M. A $\beta$-induced microglial cell activation is inhibited by baicalin through the JAK2/STAT3 signaling pathway. Int. J. Neurosci. 2014, 124, 609-620. [CrossRef] [PubMed]

15. Zheng, W.X.; Wang, F.; Cao, X.L.; Pan, H.Y.; Liu, X.Y.; Hu, X.M.; Sun, Y.Y. Baicalin protects PC-12 cells from oxidative stress induced by hydrogen peroxide via anti-apoptotic effects. Brain Inj. 2014, 28, 227-234. [CrossRef] [PubMed]

16. Zuo, D.; Lin, Y.; Liu, L.; Wang, C.; Xu, J.; Sun, F.; Li, L.; Li, Z.; Wu, Y. Baicalin attenuates ketamine-induced neurotoxicity in the developing rats: Involvement of $\mathrm{PI} 3 \mathrm{~K} / \mathrm{Akt}$ and $\mathrm{CREB} / \mathrm{BDNF} / \mathrm{Bcl}-2$ pathways. Neurotox. Res. 2016, 30, 159-172. [CrossRef] [PubMed]

17. Tejada, S.; Setzer, W.; Daglia, M.; Nabavi, S.F.; Sureda, A.; Braidy, N.; Gortzi, O.; Nabavi, S.M. Neuroprotective effects of ellagitannins: A brief review. Curr. Drug Targets 2016, 7, 26-33. [CrossRef] [PubMed] 
18. Hsieh, H.L.; Yang, C.M. Role of redox signaling in neuroinflammation and neurodegenerative disease. BioMed Res. Int. 2013, 2013, 484613. [CrossRef] [PubMed]

19. Sowndhararajan, K.; Deepa, P.; Kim, M.; Park, S.J.; Kim, S. Baicalein as a potent neuroprotective agent: A review. Biomed. Pharmacother. 2017, 95, 1021-1032. [CrossRef] [PubMed]

20. Cao, Y.; Li, G.; Wang, Y.F.; Fan, Z.K.; Yu, D.S.; Wang, Z.D.; Bi, Y.L. Neuroprotective effect of baicalin on compression spinal cord injury in rats. Brain Res. 2010, 1357, 115-123. [CrossRef] [PubMed]

21. Zheng, W.X.; Cao, X.L.; Wang, F.; Wang, J.; Ying, T.Z.; Xiao, W.; Zhang, Y.; Xing, H.; Dong, W.; Xu, S.Q.; et al. Baicalin inhibiting cerebral ischemia/hypoxia-induced neuronal apoptosis via MRTF-A-mediated transactivity. Eur. J. Pharmacol. 2015, 767, 201-210. [CrossRef] [PubMed]

22. Bao-An, C.; Senthilkumar, R.; Rong, F.; Guo, Q.L. Cardioprotective potential of baicalein: A short review of in vitro and in vivo studies. Pharm. Anal. Acta 2014, 5, 280-284.

23. de Oliveira, M.R.; Nabavi, S.F.; Habtemariam, S.; Erdogan Orhan, I.; Daglia, M.; Nabavi, S.M. The effects of baicalein and baicalin on mitochondrial function and dynamics: A review. Pharmacol. Res. 2015, 100, $296-308$. [CrossRef] [PubMed]

24. Gao, Y.; Snyder, S.A.; Smith, J.N.; Chen, Y.C. Anticancer properties of baicalein: A review. Med. Chem. Res. 2016, 25, 1515-1523. [CrossRef] [PubMed]

25. Xiao, J.R.; Do, C.W.; To, C.H. Potential therapeutic effects of baicalein, baicalin and wogonin in ocular disorders. J. Ocul. Pharmacol. Ther. 2014, 30, 605-614. [CrossRef] [PubMed]

26. Lai, M.Y.; Hsiu, S.L.; Tsai, S.Y.; Hou, Y.C.; Chao, P.D.L. Comparison of metabolic pharmacokinetics of baicalin and baicalein in rats. J. Pharm. Pharmacol. 2003, 55, 205-209. [CrossRef] [PubMed]

27. Tian, S.; Du, L.; Wang, S.; He, G.; Yang, T.; Li, X. Pharmacokinetic study of baicalein and its major metabolites after IV administration in dogs. Chin. Herb. Med. 2011, 3, 196-201.

28. Dou, J.; Chen, L.; Xu, G.; Zhang, L.; Zhou, H.; Wang, H.; Su, Z.; Ke, M.; Guo, Q.; Zhou, C. Effects of baicalein on sendai virus in vivo are linked to serum baicalin and its inhibition of hemagglutinin-neuraminidase. Arch. Virol. 2011, 156, 793-801. [CrossRef] [PubMed]

29. Jang, S.I.; Kim, H.J.; Hwang, K.M.; Jekal, S.J.; Pae, H.O.; Choi, B.M.; Yun, Y.G.; Kwon, T.O.; Chung, H.T.; Kim, Y.C. Hepatoprotective effect of baicalin, a major flavone from Scutellaria radix, on acetaminophen-induced liver injury in mice. Immunopharmacol. Immunotoxicol. 2003, 25, 585-594. [CrossRef] [PubMed]

30. Liu, L.Y.; Wei, E.Q.; Zhao, Y.M.; Chen, F.X.; Wang, M.L.; Zhang, W.P.; Chen, Z. Protective effects of baicalin on oxygen/glucose deprivation- and NMDA-induced injuries in rat hippocampal slices. J. Pharm. Pharmacol. 2005, 57, 1019-1026. [CrossRef] [PubMed]

31. Ge, Q.F.; Hu, X.; Ma, Z.Q.; Liu, J.R.; Zhang, W.P.; Chen, Z.; Wei, E.Q. Baicalin attenuates oxygen-glucose deprivation-induced injury via inhibiting NMDA receptor-mediated 5-lipoxygenase activation in rat cortical neurons. Pharmacol. Res. 2007, 55, 148-157. [CrossRef] [PubMed]

32. Jung, S.H.; Kang, K.D.; Ji, D.; Fawcett, R.J.; Safa, R.; Kamalden, T.A.; Osborne, N.N. The flavonoid baicalin counteracts ischemic and oxidative insults to retinal cells and lipid peroxidation to brain membranes. Neurochem. Int. 2008, 53, 325-337. [CrossRef] [PubMed]

33. Tarragó, T.; Kichik, N.; Claasen, B.; Prades, R.; Teixidó, M.; Giralt, E. Baicalin, a prodrug able to reach the CNS, is a prolyl oligopeptidase inhibitor. Bioorg. Med. Chem. 2008, 16, 7516-7524. [CrossRef] [PubMed]

34. Li, H.; Hu, J.; Ma, L.; Yuan, Z.; Wang, Y.; Wang, X.; Xing, D.; Lei, F.; Du, L. Comprehensive study of baicalin down-regulating NOD2 receptor expression of neurons with oxygen-glucose deprivation in vitro and cerebral ischemia-reperfusion in vivo. Eur. J. Pharmacol. 2010, 649, 92-99. [CrossRef] [PubMed]

35. Yin, F.; Liu, J.; Ji, X.; Wang, Y.; Zidichouski, J.; Zhang, J. Baicalin prevents the production of hydrogen peroxide and oxidative stress induced by A $\beta$ aggregation in SH-SY5Y cells. Neurosci. Lett. 2011, 492, 76-79. [CrossRef] [PubMed]

36. Hou, J.; Wang, J.; Zhang, P.; Li, D.; Zhang, C.; Zhao, H.; Fu, J.; Wang, B.; Liu, J. Baicalin attenuates proinflammatory cytokine production in oxygen-glucose deprived challenged rat microglial cells by inhibiting TLR4 signaling pathway. Int. Immunopharmacol. 2012, 14, 749-757. [CrossRef] [PubMed]

37. Li, Y.; Zhuang, P.; Shen, B.; Zhang, Y.; Shen, J. Baicalin promotes neuronal differentiation of neural stem/progenitor cells through modulating p-stat3 and bHLH family protein expression. Brain Res. 2012, 1429, 36-42. [CrossRef] [PubMed] 
38. Cheng, F.; Lu, Y.; Zhong, X.; Song, W.; Wang, X.; Sun, X.; Qin, J.; Guo, S.; Wang, Q. Baicalin's therapeutic time window of neuroprotection during transient focal cerebral ischemia and its antioxidative effects in vitro and in vivo. Evid. Based Complement. Alternat. Med. 2013, 2013, 120261. [CrossRef] [PubMed]

39. Jiang, H.; Lv, P.; Li, J.; Wang, H.; Zhou, T.; Liu, Y.; Lin, W. Baicalin inhibits colistin sulfate-induced apoptosis of PC12 cells. Neural Regen. Res. 2013, 8, 2597-2604. [PubMed]

40. Xu, M.; Chen, X.; Gu, Y.; Peng, T.; Yang, D.; Chang, R.C.; So, K.F.; Liu, K.; Shen, J. Baicalin can scavenge peroxynitrite and ameliorate endogenous peroxynitrite-mediated neurotoxicity in cerebral ischemiareperfusion injury. J. Ethnopharmacol. 2013, 150, 116-124. [CrossRef] [PubMed]

41. Zhang, P.; Hou, J.; Fu, J.; Li, D.; Zhang, C.; Liu, J. Baicalin protects rat brain microvascular endothelial cells injured by oxygen-glucose deprivation via anti-inflammation. Brain Res. Bull. 2013, 97, 8-15. [CrossRef] [PubMed]

42. Zhuang, P.W.; Cui, G.Z.; Zhang, Y.J.; Zhang, M.X.; Guo, H.; Zhang, J.B.; Lu, Z.Q.; Isaiah, A.O.; Lin, Y.X. Baicalin regulates neuronal fate decision in neural stem/progenitor cells and stimulates hippocampal neurogenesis in adult rats. CNS Neurosci. Ther. 2013, 19, 154-162. [CrossRef] [PubMed]

43. Guo, C.; Chen, X.; Xiong, P. Baicalin suppresses iron accumulation after substantia nigra injury: Relationship between iron concentration and transferrin expression. Neural Regen. Res. 2014, 9, 630-636. [PubMed]

44. Morita, A.; Soga, K.; Nakayama, H.; Ishida, T.; Kawanishi, S.; Sato, E.F. Neuronal differentiation of human iPS cells induced by baicalin via regulation of bHLH gene expression. Biochem. Biophys. Res. Commun. 2015, 465, 458-463. [CrossRef] [PubMed]

45. Zhou, R.; Han, X.; Wang, J.; Sun, J. Baicalin may have a therapeutic effect in attention deficit hyperactivity disorder. Med. Hypotheses 2015, 85, 761-764. [CrossRef] [PubMed]

46. Wang, P.; Cao, Y.; Yu, J.; Liu, R.; Bai, B.; Qi, H.; Zhang, Q.; Guo, W.; Zhu, H.; Qu, L. Baicalin alleviates ischemia-induced memory impairment by inhibiting the phosphorylation of CaMKII in hippocampus. Brain Res. 2016, 1642, 95-103. [CrossRef] [PubMed]

47. Zhang, C.; Zhao, R.; Yan, W.; Wang, H.; Jia, M.; Zhu, N.; Zhu, Y.; Zhang, Y.; Wang, P.; Lei, H. Compositions, formation mechanism, and neuroprotective effect of compound precipitation from the traditional Chinese prescription Huang-Lian-Jie-Du-Tang. Molecules 2016, 21, 1094. [CrossRef] [PubMed]

48. Luo, S.; Li, S.; Zhu, L.; Fang, S.H.; Chen, J.L.; Xu, Q.Q.; Li, H.Y.; Luo, N.C.; Yang, C.; Luo, D.; et al. Effect of baicalin on oxygen-glucose deprivation-induced endothelial cell damage. Neuroreport 2017, 28, 299-306. [CrossRef] [PubMed]

49. Zuo, W.; Wu, H.; Zhang, K.; Lv, P.; Xu, F.; Jiang, W.; Zheng, L.; Zhao, J. Baicalin promotes the viability of Schwann cells in vitro by regulating neurotrophic factors. Exp. Ther. Med. 2017, 14, 507-514. [CrossRef] [PubMed]

50. Ding, S.; Zhuge, W.; Hu, J.; Yang, J.; Wang, X.; Wen, F.; Wang, C.; Zhuge, Q. Baicalin reverses the impairment of synaptogenesis induced by dopamine burden via the stimulation of $\mathrm{GABA}_{\mathrm{A}} \mathrm{R}$-TrkB interaction in minimal hepatic encephalopathy. Psychopharmacology 2018, 235, 1163-1178. [CrossRef] [PubMed]

51. Li, H.; Wang, H.; Chen, J.H.; Wang, L.H.; Zhang, H.S.; Fan, Y. Determination of amino acid neurotransmitters in cerebral cortex of rats administered with baicalin prior to cerebral ischemia by capillary electrophoresis-laser-induced fluorescence detection. J. Chromatogr. B Analyt. Technol. Biomed. Life Sci. 2003, 788, 93-101. [CrossRef]

52. Liao, J.F.; Hung, W.Y.; Chen, C.F. Anxiolytic-like effects of baicalein and baicalin in the Vogel conflict test in mice. Eur. J. Pharmacol. 2003, 464, 141-146. [CrossRef]

53. Zhang, Z.; Wang, Z.; Zhang, X.; Ying, K.; Liu, J.; Wang, Y. Gene expression profile induced by oral administration of baicalin and gardenin after focal brain ischemia in rats. Acta Pharmacol. Sin. 2005, 26, 307-314. [CrossRef] [PubMed]

54. Xu, Z.; Wang, F.; Tsang, S.Y.; Ho, K.H.; Zheng, H.; Yuen, C.T.; Chow, C.Y.; Xue, H. Anxiolytic-Like Effect of baicalin and its additivity with other anxiolytics. Planta Med. 2006, 72, 189-192. [CrossRef] [PubMed]

55. Zhang, L.; Xing, D.; Wang, W.; Wang, R.; Du, L. Kinetic difference of baicalin in rat blood and cerebral nuclei after intravenous administration of Scutellariae Radix extract. J. Ethnopharmacol. 2006, 103, 120-125. [CrossRef] [PubMed]

56. Chang, C.P.; Huang, W.T.; Cheng, B.C.; Hsu, C.C.; Lin, M.T. The flavonoid baicalin protects against cerebrovascular dysfunction and brain inflammation in experimental heatstroke. Neuropharmacology 2007, 52, 1024-1033. [CrossRef] [PubMed] 
57. Chen, X.; Zhang, N.; Zou, H.Y. Protective effect of baicalin on mouse with Parkinson's disease induced by MPTP. Zhongguo Zhong Xi Yi Jie He Za Zhi 2007, 27, 1010-1012. [PubMed]

58. Wang, F.; Xu, Z.; Ren, L.; Tsang, S.Y.; Xue, H. GABA a receptor subtype selectivity underlying selective anxiolytic effect of baicalin. Neuropharmacology 2008, 55, 1231-1237. [CrossRef] [PubMed]

59. Tu, X.K.; Yang, W.Z.; Shi, S.S.; Wang, C.H.; Chen, C.M. Neuroprotective effect of baicalin in a rat model of permanent focal cerebral ischemia. Neurochem. Res. 2009, 34, 1626-1634. [CrossRef] [PubMed]

60. Zhang, Z.; Wu, R.; Li, P.; Liu, F.; Zhang, W.; Zhang, P.; Li, P.; Wang, Y. Baicalin administration is effective in positive regulation of twenty-four ischemia/reperfusion-related proteins identified by a proteomic study. Neurochem. Int. 2009, 54, 488-496. [CrossRef] [PubMed]

61. Xue, X.; Qu, X.J.; Yang, Y.; Sheng, X.H.; Cheng, F.; Jiang, E.N.; Wang, J.H.; Bu, W.; Liu, Z.P. Baicalin attenuates focal cerebral ischemic reperfusion injury through inhibition of nuclear factor $\mathrm{\kappa B}$ p65 activation. Biochem. Biophys. Res. Commun. 2010, 403, 398-404. [CrossRef] [PubMed]

62. Cao, Y.; Mao, X.; Sun, C.; Zheng, P.; Gao, J.; Wang, X.; Min, D.; Sun, H.; Xie, N.; Cai, J. Baicalin attenuates global cerebral ischemia/reperfusion injury in gerbils via anti-oxidative and anti-apoptotic pathways. Brain Res. Bull. 2011, 85, 396-402. [CrossRef] [PubMed]

63. Tu, X.K.; Yang, W.Z.; Liang, R.S.; Shi, S.S.; Chen, J.P.; Chen, C.M.; Wang, C.H.; Xie, H.S.; Chen, Y.; Ouyang, L.Q. Effect of baicalin on matrix metalloproteinase-9 expression and blood-brain barrier permeability following focal cerebral ischemia in rats. Neurochem. Res. 2011, 36, 2022-2028. [CrossRef] [PubMed]

64. Tu, X.K.; Yang, W.Z.; Shi, S.S.; Chen, Y.; Wang, C.H.; Chen, C.M.; Chen, Z. Baicalin inhibits TLR2/4 signaling pathway in rat brain following permanent cerebral ischemia. Inflammation 2011, 34, 463-470. [CrossRef] [PubMed]

65. Cheng, O.; Li, Z.; Han, Y.; Jiang, Q.; Yan, Y.; Cheng, K. Baicalin improved the spatial learning ability of global ischemia/reperfusion rats by reducing hippocampal apoptosis. Brain Res. 2012, 1470, 111-118. [CrossRef] [PubMed]

66. Gaire, B.P.; Song, J.; Lee, S.H.; Kim, H. Neuroprotective effect of four flavonoids in the root of Scutellaria baicalensis Georgi. Planta Med. 2012, 78, PF71. [CrossRef]

67. Liu, Y.F.; Gao, F.; Li, X.W.; Jia, R.H.; Meng, X.D.; Zhao, R.; Jing, Y.Y.; Wang, Y.; Jiang, W. The anticonvulsant and neuroprotective effects of baicalin on pilocarpine-induced epileptic model in rats. Neurochem. Res. 2012, 37, 1670-1680. [CrossRef] [PubMed]

68. Ma, S.; Zhao, M.; Liu, H.; Wang, L.; Zhang, X. Pharmacokinetic effects of baicalin on cerebral ischemia-reperfusion after iv administration in rats. Chin. Herb. Med. 2012, 4, 53-57.

69. Xiong, P.; Chen, X.; Guo, C.; Zhang, N.; Ma, B. Baicalin and deferoxamine alleviate iron accumulation in different brain regions of Parkinson's disease rats. Neural Regen. Res. 2012, 7, 2092-2098. [PubMed]

70. Zhou, Q.B.; Jia, Q.; Zhang, Y.; Li, L.Y.; Chi, Z.F.; Liu, P. Effects of baicalin on protease-activated receptor-1 expression and brain injury in a rat model of intracerebral hemorrhage. Chin. J. Physiol. 2012, 55, 202-209. [CrossRef] [PubMed]

71. Dai, J.; Chen, L.; Qiu, Y.M.; Li, S.Q.; Xiong, W.H.; Yin, Y.H.; Jia, F.; Jiang, J.Y. Activations of GABAergic signaling, HSP70 and MAPK cascades are involved in baicalin's neuroprotection against gerbil global ischemia/reperfusion injury. Brain Res. Bull. 2013, 90, 1-9. [CrossRef] [PubMed]

72. Li, H.; Zhang, Y.; Yu, Y.; Li, B.; Chen, Y.; Wu, H.; Wang, J.; Li, J.; Xiong, X.; He, Q.; et al. Systemic revealing pharmacological signalling pathway networks in the hippocampus of ischaemia-reperfusion mice treated with baicalin. Evid. Based Complement. Alternat. Med. 2013, 2013, 630723. [CrossRef] [PubMed]

73. Li, Y.C.; Shen, J.D.; Li, J.; Wang, R.; Jiao, S.; Yi, L.T. Chronic treatment with baicalin prevents the chronic mild stress-induced depressive-like behavior: Involving the inhibition of cyclooxygenase-2 in rat brain. Prog. Neuropsychopharmacol. Biol. Psychiatry 2013, 40, 138-143. [CrossRef] [PubMed]

74. Zhang, J.; Li, P.; Wang, Y.; Liu, J.; Zhang, Z.; Cheng, W.; Wang, Y. Ameliorative effects of a combination of baicalin, jasminoidin and cholic acid on ibotenic acid-induced dementia model in rats. PLoS ONE 2013, 8, e56658.

75. Lee, B.; Sur, B.; Shim, I.; Lee, H.; Hahm, D.H. Baicalin improves chronic corticosterone-induced learning and memory deficits via the enhancement of impaired hippocampal brain-derived neurotrophic factor and cAMP response element-binding protein expression in the rat. J. Nat. Med. 2014, 68, 132-143. [CrossRef] [PubMed] 
76. Yu, H.; Yin, Z.; Yang, S.; Ma, S. Baicalin reverse AMPA receptor expression and neuron apoptosis in chronic unpredictable mild stress rats. Biochem. Biophys. Res. Commun. 2014, 451, 467-472. [CrossRef] [PubMed]

77. Zhou, Q.B.; Jin, Y.L.; Jia, Q.; Zhang, Y.; Li, L.Y.; Liu, P.; Liu, Y.T. Baicalin attenuates brain edema in a rat model of intracerebral hemorrhage. Inflammation 2014, 37, 107-115. [CrossRef] [PubMed]

78. Chen, C.; Li, X.; Gao, P.; Tu, Y.; Zhao, M.; Li, J.; Zhang, S.; Liang, H. Baicalin attenuates alzheimer-like pathological changes and memory deficits induced by amyloid $\beta_{1-42}$ protein. Metab. Brain Dis. 2015, 30, 537-544. [CrossRef] [PubMed]

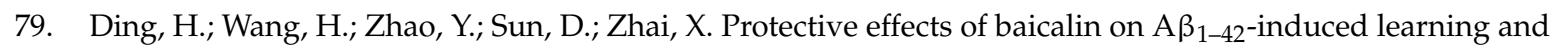
memory deficit, oxidative stress, and apoptosis in rat. Cell Mol. Neurobiol. 2015, 35, 623-632. [CrossRef] [PubMed]

80. Li, Y.C.; Wang, L.L.; Pei, Y.Y.; Shen, J.D.; Li, H.B.; Wang, B.Y.; Bai, M. Baicalin decreases SGK1 expression in the hippocampus and reverses depressive-like behaviors induced by corticosterone. Neuroscience 2015, 311, 130-137. [CrossRef] [PubMed]

81. Ma, P.; Mao, X.Y.; Li, X.L.; Ma, Y.; Qiao, Y.D.; Liu, Z.Q.; Zhou, H.H.; Cao, Y.G. Baicalin alleviates diabetesassociated cognitive deficits via modulation of mitogen-activated protein kinase signaling, brain-derived neurotrophic factor and apoptosis. Mol. Med. Rep. 2015, 12, 6377-6383. [CrossRef] [PubMed]

82. Dang, H.; Li, K.; Yu, Y.; Zhang, Y.; Liu, J.; Wang, P.; Li, B.; Wang, H.; Li, H.; Wang, Z.; et al. Variation of pathways and network profiles reveals the differential pharmacological mechanisms of each effective component to treat middle cerebral artery ischemia-reperfusion mice. Exp. Biol. Med. 2016, 241, 79-89. [CrossRef] [PubMed]

83. Liao, Z.J.; Liang, R.S.; Shi, S.S.; Wang, C.H.; Yang, W.Z. Effect of baicalin on hippocampal damage in kainic acid-induced epileptic mice. Exp. Ther. Med. 2016, 12, 1405-1411. [CrossRef] [PubMed]

84. Yu, H.Y.; Yin, Z.J.; Yang, S.J.; Ma, S.P.; Qu, R. Baicalin reverses depressive-like behaviours and regulates apoptotic signalling induced by olfactory bulbectomy. Phytother. Res. 2016, 30, 469-475. [CrossRef] [PubMed]

85. Bitto, A.; Giuliani, D.; Pallio, G.; Irrera, N.; Vandini, E.; Canalini, F.; Zaffe, D.; Ottani, A.; Minutoli, L.; Rinaldi, M.; et al. Effects of COX1-2/5-LOX blockade in Alzheimer transgenic 3xTg-AD mice. Inflamm. Res. 2017, 66, 389-398. [CrossRef] [PubMed]

86. Chen, H.; Guan, B.; Chen, X.; Chen, X.; Li, C.; Qiu, J.; Yang, D.; Liu, K.J.; Qi, S.; Shen, J. Baicalin attenuates blood-brain barrier disruption and hemorrhagic transformation and improves neurological outcome in ischemic stroke rats with delayed t-PA treatment: Involvement of ONOO-MMP-9 pathway. Transl. Stroke Res. 2017. [CrossRef] [PubMed]

87. Liu, Q.; Liu, J.; Wang, P.; Zhang, Y.; Li, B.; Yu, Y.; Dang, H.; Li, H.; Zhang, X.; Wang, Z. Poly-dimensional network comparative analysis reveals the pure pharmacological mechanism of baicalin in the targeted network of mouse cerebral ischemia. Brain Res. 2017, 1666, 70-79. [CrossRef] [PubMed]

88. Shi, X.; Fu, Y.; Zhang, S.; Ding, H.; Chen, J. Baicalin attenuates subarachnoid hemorrhagic brain injury by modulating blood-brain barrier disruption, inflammation, and oxidative damage in mice. Oxid. Med. Cell Longev. 2017, 2017, 1401790. [CrossRef] [PubMed]

89. Zhou, Z.Q.; Li, Y.L.; Ao, Z.B.; Wen, Z.L.; Chen, Q.W.; Huang, Z.G.; Xiao, B.; Yan, X.H. Baicalin protects neonatal rat brains against hypoxic-ischemic injury by upregulating glutamate transporter 1 via the phosphoinositide 3-kinase/protein kinase B signaling pathway. Neural Regen. Res. 2017, 12, 1625-1631. [PubMed]

90. Gao, C.; Du, Q.; Li, W.; Deng, R.; Wang, Q.; Xu, A.; Shen, J. Baicalin modulates APPL2/glucocorticoid receptor signaling cascade, promotes neurogenesis, and attenuates emotional and olfactory dysfunctions in chronic corticosterone-induced depression. Mol. Neurobiol. 2018. [CrossRef] [PubMed]

91. Zhao, J.; Lu, S.; Yu, H.; Duan, S.; Zhao, J. Baicalin and ginsenoside Rb1 promote the proliferation and differentiation of neural stem cells in Alzheimer's disease model rats. Brain Res. 2018, 1678, 187-194. [CrossRef] [PubMed]

92. Zhu, W.; Ma, S.; Qu, R.; Kang, D.; Liu, Y. Antidepressant effect of baicalin extracted from the root of Scutellaria baicalensis in mice and rats. Pharm. Biol. 2006, 44, 503-510. [CrossRef]

93. Zhang, K.; Pan, X.; Wang, F.; Ma, J.; Su, G.; Dong, Y.; Yang, J.; Wu, C. Baicalin promotes hippocampal neurogenesis via SGK1- and FKBP5-mediated glucocorticoid receptor phosphorylation in a neuroendocrine mouse model of anxiety/depression. Sci. Rep. 2016, 6, 30951. [CrossRef] [PubMed] 
94. Zhang, D.M.; Liu, H.Y.; Xie, L.; Liu, X.D. Effect of baicalin and berberine on transport of nimodipine on primary-cultured, rat brain microvascular endothelial cells. Acta Pharmacol. Sin. 2007, 28, 573-578. [CrossRef] [PubMed]

95. Liu, Z.; Zhang, L.; He, Q.; Liu, X.; Okeke, C.I.; Tong, L.; Guo, L.; Yang, H.; Zhang, Q.; Zhao, H.; et al. Effect of Baicalin-loaded PEGylated cationic solid lipid nanoparticles modified by OX26 antibody on regulating the levels of baicalin and amino acids during cerebral ischemia-reperfusion in rats. Int. J. Pharm. 2015, 489, 131-138. [CrossRef] [PubMed]

96. Liu, Z.; Zhao, H.; Shu, L.; Zhang, Y.; Okeke, C.; Zhang, L.; Li, J.; Li, N. Preparation and evaluation of Baicalin-loaded cationic solid lipid nanoparticles conjugated with OX26 for improved delivery across the BBB. Drug Dev. Ind. Pharm. 2015, 41, 353-361. [CrossRef] [PubMed]

97. Li, N.; Je, Y.J.; Yang, M.; Jiang, X.H.; Ma, J.H. Pharmacokinetics of baicalin-phospholipid complex in rat plasma and brain tissues after intranasal and intravenous administration. Pharmazie 2011, 66, 374-377. [PubMed]

98. Zhang, Z.J.; Li, P.; Wang, Z.; Li, P.T.; Zhang, W.S.; Sun, Z.H.; Zhang, X.J.; Wang, Y.Y. A comparative study on the individual and combined effects of baicalin and jasminoidin on focal cerebral ischemia-reperfusion injury. Brain Res. 2006, 1123, 188-195. [CrossRef] [PubMed]

99. Yang, Y.F.; Li, Z.; Xin, W.F.; Wang, Y.Y.; Zhang, W.S. Pharmacokinetics and brain distribution differences of baicalin in rat underlying the effect of Panax notoginsenosides after intravenous administration. Chin. J. Nat. Med. 2014, 12, 632-640. [CrossRef]

100. Fong, S.Y.K.; Li, C.; Ho, Y.C.; Li, R.; Wang, Q.; Wong, Y.C.; Xue, H.; Zuo, Z. Brain uptake of bioactive flavones in Scutellariae Radix and its relationship to anxiolytic effect in mice. Mol. Pharm. 2017, 14, 2908-2916. [CrossRef] [PubMed]

(C) 2018 by the authors. Licensee MDPI, Basel, Switzerland. This article is an open access article distributed under the terms and conditions of the Creative Commons Attribution (CC BY) license (http:/ / creativecommons.org/licenses/by/4.0/). 